Linköping University Medical Dissertation

No. 1446

\title{
Sleep disorders \\ during pregnancy
}

Maria Sarberg

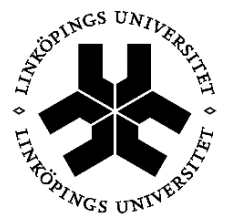

Linköping University

FACULTY OF HEALTH SCIENCES

Department of Obstetrics and Gynaecology and Department of Clinical and Experimental Medicine Linköping University, Linköping, Sweden Linköping 2015 
Sleep disorders during pregnancy

(C) Maria Sarberg

ISBN 978-91-7519-121-8

ISSN 0345-0082

Cover illustration: Tilde Söderberg 2015

Printed by LiU-tryck, Linköping, Sweden 2015 


\section{Abstract}

\section{Background}

Sleep disorders are known to increase in prevalence during pregnancy, and associations between disturbed sleep during pregnancy and adverse outcomes for mother and child have been reported in a number of studies. However, most of these studies were retrospective and too small to satisfactorily demonstrate the association.

\section{Aims}

- $\quad$ To prospectively investigate the development of snoring during pregnancy and assess if there is an association between snoring and sleepiness or adverse pregnancy outcomes.

- To study the development of restless legs syndrome during and after pregnancy, and whether it is associated with snoring or other pregnancy-related symptoms.

- To investigate the possible association between depressive symptoms in the postpartum period and sleep related problems during pregnancy, using screening instruments.

- $\quad$ To objectively evaluate sleep disordered breathing in pregnant women compared to non-pregnant controls and to evaluate differences in Epworth Sleepiness Scale scores between the two groups.

\section{Methods}

Questionnaires containing subjective rating of snoring, Epworth Sleepiness Scale and symptoms of restless legs were used in all studies. Information from the medical records of the pregnant women was also utilized. For objective evaluation of sleep disordered breathing, nocturnal respiratory recordings were used. In the research for the first three papers the same cohort of 500 pregnant women was followed on three occasions during pregnancy and also after delivery, and for the last paper, 100 other pregnant women were compared to 80 non-pregnant controls.

\section{Results and conclusions}

Both snoring and restless legs syndrome increase during pregnancy, but this had no convincing impact on obstetric outcome. Sleep recordings could not verify an increased prevalence of obstructive sleep apnea among pregnant women. Restless legs syndrome was associated with snoring and could persist after delivery. Women who had high scores on the Epworth Sleepiness Scale in the last trimester of pregnancy showed more depressive symptoms in the postpartum period. No difference in item scoring of the Epworth Sleepiness Scale was found between pregnant women and controls. 


\section{Contents}

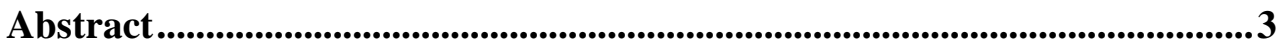

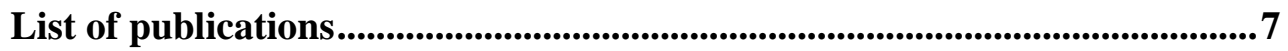

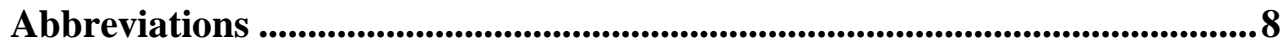

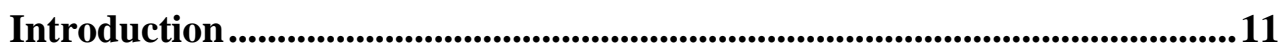

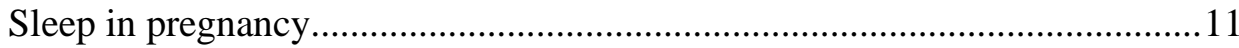

Snoring, sleep disordered breathing and obstructive sleep apnea ...................14

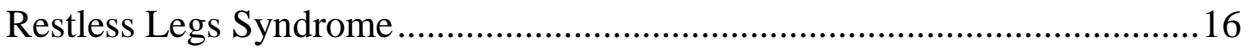

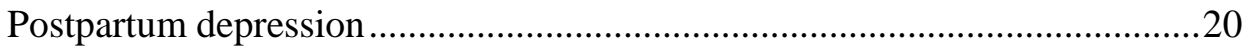

Adverse outcomes of pregnancy with possible association with sleep

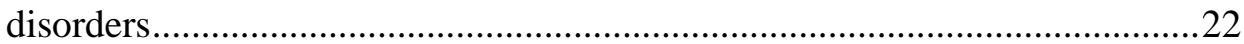

Specific background of the studies in the thesis...........................................23

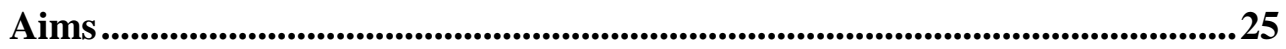

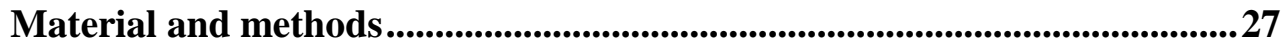

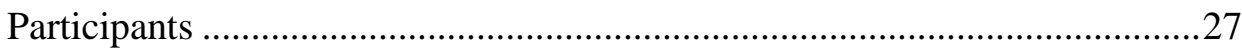

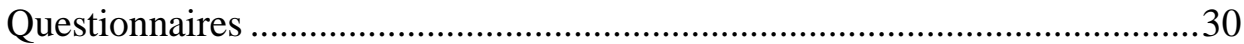

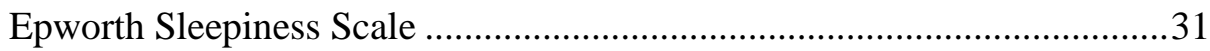

Edinburgh Postnatal Depression Scale .......................................................32

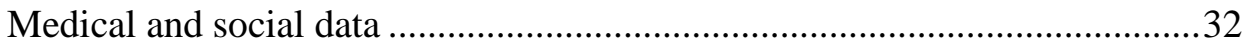

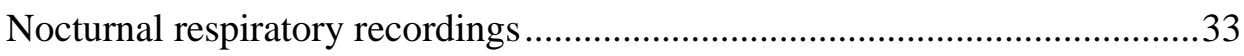

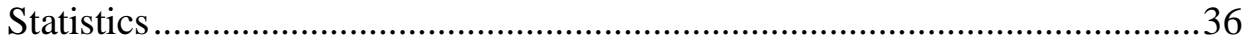

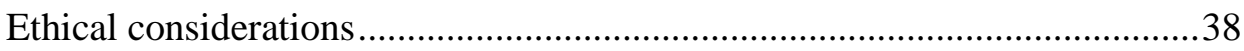

Results and comments ............................................................................................41

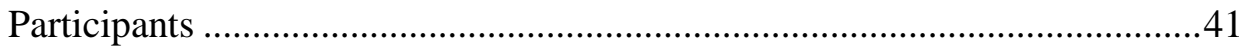

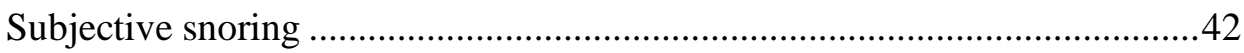

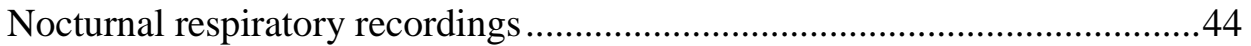

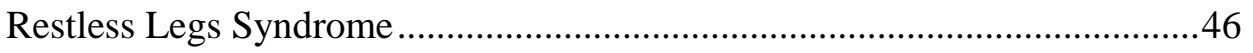

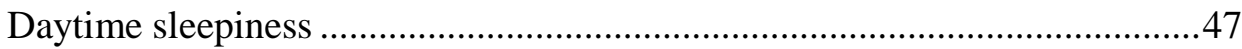

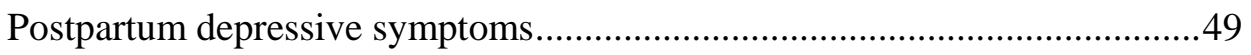


Obstetric outcomes .50

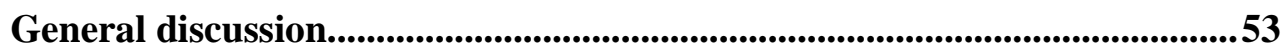

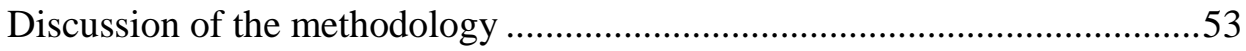

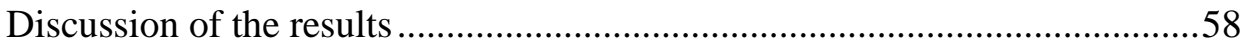

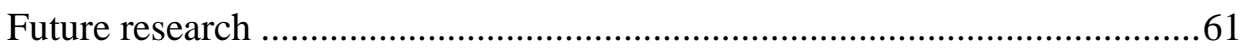

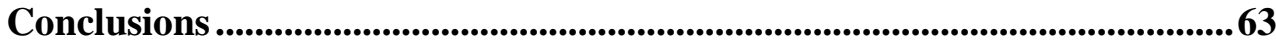

Populärvetenskaplig sammanfattning på svenska...........................................65

Acknowledgements............................................................................................................667

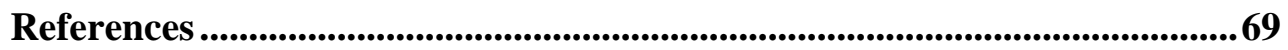

Appendix 1 ...................................................................................................................78

Appendix 2 .................................................................................................................79

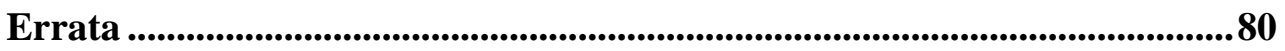





\section{List of publications}

I. Sarberg M, Svanborg E, Wiréhn AB, Josefsson A. Snoring during pregnancy and its relation to sleepiness and pregnancy outcome - a prospective study. BMC Pregnancy and Childbirth 2014;14:15.

II. Sarberg M, Josefsson A, Wiréhn AB, Svanborg E. Restless legs syndrome during and after pregnancy and its relation to snoring. Acta Obstet Gynecol Scand 2012;91:850-855.

III. Sarberg M, Bladh M, Svanborg E, Josefsson A. Postpartum depressive symptoms and its association to daytime sleepiness and restless legs during pregnancy. Under review.

IV. Sarberg M, Bladh M, Josefsson A, Svanborg E. Snoring, sleepiness and sleep disordered breathing during pregnancy. Under review.

The published papers are reprinted with permission from the publishers. 


\title{
Abbreviations
}

\section{with explanations}

$\mathrm{ACC}$

\author{
Antenatal Care Center \\ Preventive healthcare with the goal of providing regular check-ups that allow \\ doctors or midwives to treat and prevent potential health problems throughout \\ the course of the pregnancy while promoting healthy lifestyles that benefit both \\ mother and child.
}

AHI

\section{Apnea/Hypopnea Index}

Sleep recording term. The average sum of apneas and hypopneas per hour of sleep.

\section{Apgar Score}

Score used to assess the health of newborn children immediately after birth, maximum score is 10. An Apgar score below 7 at 5 minutes age is a sign that the baby needs medical attention.

\section{Body Mass Index}

Clinically widely used measure of relative size of an individual, based on the mass and height. Calculated as body mass divided by the square of height $\left(\mathrm{kg} / \mathrm{m}^{2}\right)$.

\section{Confidence Interval}

Statistical term. A type of interval estimate that acts as a good estimate of the unknown population parameter. The level of confidence of the confidence interval (e.g. 95\%) would indicate the probability that the confidence range captures this true population parameter.

CPAP Continuous Positive Airway Pressure

A technique of respiratory therapy in which airway pressure is maintained above atmospheric pressure throughout the respiratory cycle by pressurization of the ventilatory circuit.

DIF

\section{Different Items Functioning}

Statistical term. Way of investigating different items of e.g. a questionnaire using ordinal regression.

\section{EEG Electroencephalography}

The recording of the brain's spontaneous electrical activity, as recorded from multiple electrodes placed on the scalp. 


\section{Excessive Daytime Sleepiness}

Persistent sleepiness, even after apparently adequate or even prolonged night time sleep. Often identified using screening tools such as Epworth Sleepiness Scale (in this thesis EDS is defined as ESS $\geq 10$ ).

EPDS

\section{Edinburgh Postnatal Depression Scale}

Screening instrument for PPD using a 10 item self-report scale for measuring common symptoms of depression. Maximum score is 30 .

ESS Epworth Sleepiness Scale

Screening instrument for daytime sleepiness. The respondent is asked to rate the risk of falling asleep in eight different situations. Maximum score is 24 .

NREM Non Rapid Eye Movement (Sleep)

Joint term for sleep stages N1-3.

ODI Oxygen Desaturation Index

Sleep recording term. The average number of drops in saturation per hour of sleep.

OR Odds Ratio

Statistical term. A measure quantifying how strongly the presence or absence of one property is associated with the presence or absence of another property in a given population. Plays an important role in logistic regression.

OSA Obstructive Sleep Apnea

Repetitive complete obstruction (apnea) or partial obstruction (hypopnea) of the collapsible part of the upper airway during sleep.

PLMD Periodic Limb Movement Disorder

Periodic episodes of repetitive limb movements caused by contractions of the muscles during sleep, often associated with RLS.

PPD Postpartum Depression

Major depression occurring in the period after giving birth.

\section{Polysomnography}

A sleep recording consisting of measurements of electrical activity in the brain, eyes and muscles, often in combination with measurements of breathing, heart rate and oxygen saturation. 
Sleep stage characterized by rapid eye movements, low muscle tone and a rapid, low-voltage EEG.

\section{RLS Restless Legs Syndrome}

Neurologic disease affecting most commonly the legs, characterized by an urge to move the affected body part accompanied by uncomfortable sensations, worsening at rest.

SD

\section{Standard Deviation}

Statistical term. A measure that is used to quantify the amount of variation of a set of data values. A standard deviation close to 0 indicates that the data points tend to be very close to the mean of the set.

\section{SDB Sleep Disordered Breathing}

An umbrella term for several chronic breathing conditions associated with snoring.

\section{SGA Small for Gestational Age}

SGA babies are those who are smaller in size than normal for the gestational age, most commonly defined as a weight below the 10th percentile for the gestational age.

\section{Slow Wave Sleep}

Stage 3 of non-rapid eye movement sleep (N3), when the EEG activity is synchronized, producing slow waves. Often referred to as deep sleep. 


\section{Introduction}

\section{Sleep in pregnancy}

Almost every woman experiences changed, usually impaired sleep when pregnant. There are many possible causes of this. Two conditions known to affect sleep, both of which increase in prevalence during pregnancy, are snoring and restless legs syndrome (RLS). Both these sleep disorders are influenced by female sex hormones (1-3) and are also related to inflammatory processes $(4,5)$. They are therefore likely to affect both each other and pregnancy-related conditions, which in turn might affect the health of both mother and child. These pregnancyrelated conditions include, e.g. preeclampsia, growth retardation of the fetus and postpartum depression. This thesis aims to describe the development of sleep disorders during pregnancy and to investigate their possible impact on conditions affecting the mother and the expected child.

\section{Physiological changes in normal pregnancy}

During pregnancy, the body undergoes remarkable physiological changes in order to support the developing fetus and to prepare for the efforts of labor. The basis for all these changes lies in hormonal factors including signals from both the fetus and placenta. The levels of estrogens are elevated more than 100 times and of progesterone up to 200 times in late pregnancy compared to pre-pregnancy levels (6).

Already after a few weeks of pregnancy, plasma volume has increased considerably. This increase continues until the middle of the $2^{\text {nd }}$ trimester and amounts to about $40 \%$. This is probably caused by early activation of the reninangiotensin-aldosterone system due to the increased production of estrogen. Parallel to this, the production of red blood cells increases, but since the change in plasma volume is greater than the change in hematocrit, the hemoglobin value will decrease by 10-15 g/l. The need for iron increases appreciably in a pregnant woman. Intake of $10 \mathrm{mg}$ additional of iron per day is necessary for a normal pregnancy. The need for folic acid increases 10 fold. An increase of both the heart rate and stroke volume is already seen in the $1^{\text {st }}$ trimester of pregnancy. A moderate tachycardia is therefore of frequent occurrence. The peripheral vascular resistance decreases considerably during pregnancy, mostly in the uteroplacental, 
renal and cutaneous vascular beds. The vasodilation results in a decrease of the systolic blood pressure on average $5-10 \mathrm{~mm} \mathrm{Hg}$ and of the diastolic blood pressure by $10-15 \mathrm{~mm} \mathrm{Hg}$. Blood pressure is at its lowest level in the middle of the $2^{\text {nd }}$ trimester. Decreased levels of circulating albumin cause the colloid osmotic pressure in plasma to decrease, which will increase the disposition to edema. This might cause edemas in the hands and feet and in the respiratory system as well, mainly in the nasal mucosa. Most women experience a feeling of dyspnea in the last part of pregnancy. This is caused by an increased ventilation rate of $40 \%$ caused by increased tidal volume and hyperventilation due to high progesterone levels. Pressure from the growing uterus may intensify the feeling of dyspnea. An increased renal blood flow due to vasodilation results in increased glomerulus filtration. The volume of the bladder is compressed by the growing uterus resulting in an increased frequency of micturition. The stomach and bowels are cranially dislocated due to the growing uterus and the emptying of the stomach and the gut motility is slowed because of the relaxing effect of the progesterone on the smooth muscles (7).

All these physical changes during pregnancy, together with discomfort caused by the growing uterus, contractions, fetal movements, back and pelvic girdle pain will in one way or another disturb sleep for most pregnant women.

\section{Normal sleep}

Sleep is vital for all living creatures. Currently the main functions of sleep are believed to be preservation of energy in the brain; defense against inflammation in the body and homeostasis of the cortical synapses (8). Sleep is also important for somatic growth, memory consolidation and thermoregulation. Most adults sleep 6-9 hours (average of 8 hours) nightly. Normal sleep is characterized by a repeating sleep cycle (Figure 1) that can be differentiated into NREM (non rapid eye movement) sleep and REM (rapid eye movement) sleep. REM sleep is a sleep stage characterized by variable activity in the autonomous nervous system, high arousal threshold by external stimuli, generalized skeletal muscle atonia (with sparing of the diaphragm, extraocular muscles, and sphincter muscles). Dreaming is more frequent and more complex in REM sleep than in NREM sleep. NREM sleep can be further subdivided into stages N1, N2 and N3 (9). N3 is often referred to as slow wave sleep (SWS), referring to the pattern seen in the electroencephalogram. A sleep cycle refers to the period from NREM stages 1-3 ending with a period of REM sleep, but not all stages have to be present in one sleep. 


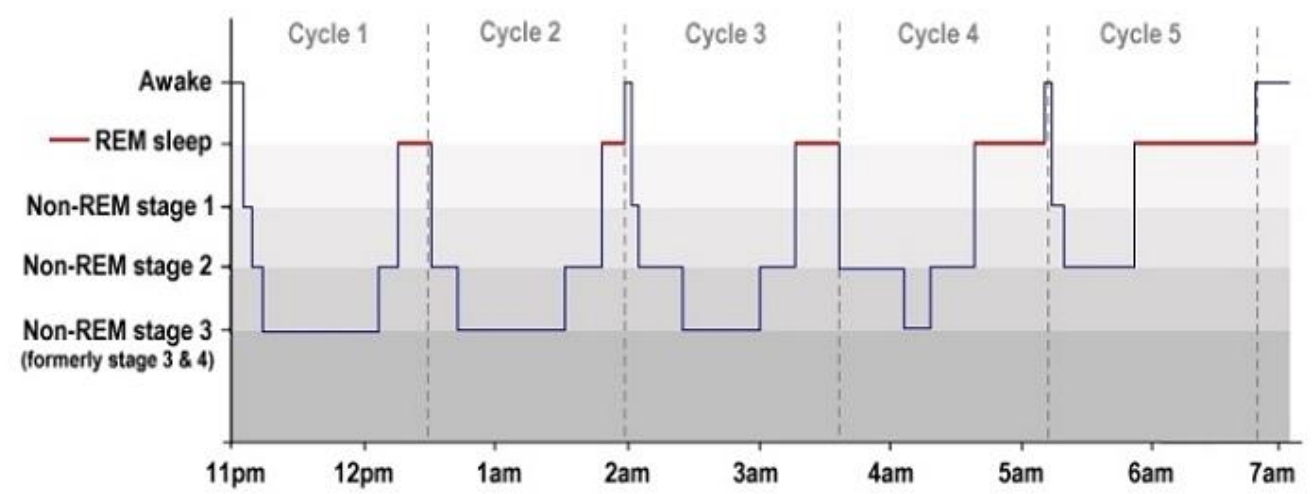

Figure 1. Sleep cycles during an ordinary night, displaying the duration of the different sleep stages. (Public domain image from www.howsleepworks.com)

cycle. There are commonly three to five NREM-REM sleep cycles, each occurring every 90 to 120 minutes during the night. NREM with stage N3 sleep predominates in the first half of the night, whereas REM sleep percentage is greatest during the second half of the night. Normal sleep in young adults is characterized by short sleep latency and few and relatively brief awakenings (10).

\section{Sleep during pregnancy}

The total sleep time varies through pregnancy, with an increased total sleep time in the $1^{\text {st }}$ trimester of pregnancy, normalized sleep time in the $2^{\text {nd }}$ trimester and decreased sleep time in the $3^{\text {rd }}$ trimester (11-13). The sleep quality also changes throughout pregnancy. A decrease in REM sleep has been reported, possibly potentiated by rising progesterone and cortisol levels. More frequent or longer awakenings are observed with increasing gestational age (14-17). However, it is difficult to draw firm conclusions on slow wave sleep (SWS) trends, as different studies report decreased SWS in the $1^{\text {st }}$ trimester $(13,15)$, increased SWS during the $2^{\text {nd }}$ trimester (17), and decreased (15), increased (17) or unchanged (16) SWS in the $3^{\text {rd }}$ trimester. Increased nocturnal awakenings are reported in the $2^{\text {nd }}$ and $3^{\text {rd }}$ trimesters of pregnancy $(11,14,16)$. Sleep disorders such as subjective snoring, sleep disordered breathing and RLS syndrome are also known to increase in prevalence during pregnancy. 


\section{Snoring, sleep disordered breathing and obstructive sleep apnea}

Snoring is a common phenomenon during sleep, which can be annoying for both the snorer and his/her partner. Snoring is reported by $27-40 \%$ of adults $(18,19)$ and may be a symptom of disturbed breathing during sleep. Sleep disordered breathing (SDB) encompasses a spectrum of snoring-associated disorders including obstructive sleep apnea (OSA), central sleep apnea and nocturnal hypoventilation; the most common is OSA (20). Snoring is present in $94 \%$ of OSA patients, but most snorers do not have OSA (21). OSA is believed to affect $9 \%$ of all women and $24 \%$ of all men in the USA (22). It is a serious and, at worst, potentially life-threatening condition characterized by repetitive pauses in breathing during sleep due to collapse of the upper airway/pharynx, which is usually accompanied by a reduction in oxygen levels in the blood, followed by an awakening to breathe. Pharyngeal collapse can be complete (causing apnea) or partial (causing hypopnea). An overnight sleep recording is required to diagnose OSA. In the sleep recording, the average sum of apneas and hypopneas per hour of sleep constitutes the apnea/hypopnea index (AHI). OSA is defined as $\mathrm{AHI} \geq 5$, however AHI 15-30 indicates moderate OSA and AHI $>30$ indicates severe OSA. Male sex, obesity, an anatomically narrow upper airway (e.g. due to fat surrounding pharynx or large tonsils), supine sleeping position, smoking and/or increased age (23) are predisposing factors. Snoring per se has also been hypothesized to cause OSA due to vibration lesions of the neurons in the upper airway (24).

Untreated OSA is associated with excessive daytime sleepiness (EDS) and reduced health-related quality of life (25). EDS is a recognized risk factor in road traffic and occupational accidents $(26,27)$. OSA is also an evident risk factor for the development of hypertension $(28,29)$. Repetitive OSA-induced hypoxemia and hypercapnia elicit reflex changes in both sympathetic and parasympathetic activation. These autonomic derangements, with consequent increases in catecholamine levels, persist even into the daytime and can contribute to the development of hypertension (30). There are also associations between OSA and cardiovascular disease (31) and metabolic syndrome (32). A meta-analysis has shown evidence indicating higher levels of markers of systemic inflammation in patients with OSA (4). Inflammatory processes are considered to play an important role in the cardiovascular pathophysiology of OSA and inflammatory 
markers associated with cardiovascular risk have been reported as elevated in patients with OSA (33).

Weight loss through lifestyle and dietary interventions results in improvements in OSA sleep but is insufficient to normalize them (34), whereas bariatric surgery can be curative (35). Non-invasive treatment with continuous positive airway pressure (CPAP) during sleep is highly effective in reducing the frequency of obstructive events in patients with mild, moderate and severe OSA and is therefore the gold standard for treatment of $\operatorname{OSA}(23,36,37)$. CPAP prevents upper airway occlusion during sleep and provides a pneumatic splint for the nasopharyngeal airway, thus allowing an entire night of uninterrupted sleep in individuals who tolerate the treatment. CPAP is also safe to use during pregnancy (38). The main adverse effects of CPAP are subjective discomfort with sleeping difficulties; pain at the bridge of the nose, skin problems, air leakage, disturbing noise from the CPAP machine and mild nasal adverse effects such as rhinitis (23).

Snoring increases during pregnancy. An American study from 1996 found a snoring rate of $4 \%$ in women before pregnancy compared to $14 \%$ in late pregnancy (39). Other studies have shown a prevalence of snoring between 2.5$45 \%$ in late pregnancy $(1,40-42)$. The most probable cause of increased snoring during pregnancy is a narrowing of the upper airways due to edema. Izci reported smaller upper airway dimensions among pregnant women compared to nonpregnant controls (1). High estradiol levels are the main cause of edemas in the airway mucosa (2) and other tissues. The prevalence of OSA in pregnancy is reported to range from 0 to $20 \%$ among normal pregnant women $(41,43,44)$. 


\section{Restless Legs Syndrome}

Restless Legs Syndrome (RLS) is characterized as paresthesias or dysesthesias, usually in the legs, causing a desire to move the limbs with immediate but temporary relief by activity, worsening of symptoms at rest and also during the evening or night. It was first described in 1945 by the Swedish neurologist Karl Axel Ekbom (45) and is also known as Willis-Ekbom disease. Four essential criteria, set by the International RLS Study Group, are all required to make the diagnosis of RLS (Box 1). These criteria were supplemented in 2012 by a fifth criterion: "The occurrence of the above features is not solely accounted for as symptoms primary to another medical or a behavioral condition (e.g., myalgia, venous stasis, leg edema, arthritis, leg cramps, positional discomfort, habitual foot tapping)". The study group has also generated a set of four questions to be used as a minimum core for population-based epidemiologic studies (Box 2) (46). Inclusion of the first three questions is mandatory if an adequate diagnostic screening is to be made; the fourth, a question that establishes frequency of symptoms, is optional but provides an important indication of the severity of the condition.

RLS is reported to affect between 5\% and 10\% of the general population (47) and is about twice as common in women as in men (48). The gender difference is explained at least in part by parity, with nulliparous women at the same risk of RLS as age-matched men, but with increasing risk for women with an increase in the number of pregnancies $(49,50)$. Symptoms of RLS can affect sleep by making it more difficult to fall asleep. However, most (80\%) people with RLS also suffer

\section{Diagnostic criteria for RLS}

1. An urge to move the legs, usually accompanied or caused by uncomfortable and unpleasant sensations in the legs.

2. The urge to move or unpleasant sensations begin or worsen during periods of rest or inactivity such as lying or sitting.

3. The urge to move or unpleasant sensations are partially or totally relieved by movement, such as walking or stretching, at least as long as the activity continues.

4. The urge to move or unpleasant sensations are worse in the evening or night than during the day or only occur in the evening or night.

Box 1. Diagnostic criteria for restless legs syndrome (RLS) set by the International RLS Study Group in 2003. 


\section{Paradigm of questions for epidemiology studies of RLS}

1. Do you have unpleasant sensations in your legs combined with an urge or need to move your legs?

2. Do these feelings occur mainly or only at rest and do they improve with movement?

3. Are these feelings worse in the evening or night than in the morning?

4. How often do these feelings occur?

(Less than one time per year; at least one time a year but less than one time per month, one time per month; 2-4 times per month; 2-3 times per week; 4-5 times per week; 6-7 times per week.)

Box 2. The set of four questions given by the International RLS Study Group to be used as a minimum core for population-based epidemiologic studies of RLS. The first three questions are mandatory for inclusion to perform an adequate diagnostic screening; the fourth is optional.

from periodic limb movement disorder (PLMD), i.e., periodic episodes of repetitive limb movements caused by contractions of the muscles during sleep (51). These movements are highly associated with nocturnal arousals causing fragmentation of sleep (52).

The etiology of RLS is only partly understood. Forty percent of persons with the syndrome have a family history of RLS (51), and specific genetic loci associated with RLS have been identified (53). The symptomatic response to dopamine agonists and levodopa is viewed as possible evidence suggesting that dysfunction of the dopaminergic system may play a role in the pathophysiology of the disease (54). There is evidence to suggest that a defect in brain iron metabolism may contribute to the pathogenesis of the disease (55). This is supported by the fact that iron is a cofactor for tyrosine hydroxylase in the reaction converting tyrosine to levodopa, which is a rate-limiting step in the production of dopamine. Therefore a decrease in iron concentration may affect the availability of dopamine. The endogenous opiate system has been suspected as having a role in the pathophysiology of RLS by stabilizing dopaminergic substantia nigra degeneration under conditions of iron deprivation (56, 57). Since many conditions associated with RLS are also associated with inflammatory/immune changes it has been suggested that RLS may be mediated or affected through inflammatory mechanisms. Inflammation is then thought to cause iron deficiency or, alternatively, immune reaction to antigens is hypothesized to cause RLS by a direct immunological attack on the central or peripheral nervous system (5). 
Another theory points out the abnormal microvascular circulation and abnormal cutaneous thermal thresholds shown in patients with RLS as a potential mechanism for the discomfort experienced in $\operatorname{RLS}(58,59)$.

RLS is often divided into primary and secondary forms. Secondary RLS is most commonly due to pregnancy, iron deficiency, and chronic kidney disease (60). However, there is a possibility that persons who are affected by secondary RLS already have an increased vulnerability for RLS triggered by the other disease.

Levodopa has been found to be effective in treating nocturnal symptoms of RLS and improving subjective and objective quality of sleep. Levodopa is a shortacting drug and a combination of slow-release levodopa and standard levodopa is superior to standard levodopa alone. Dopamine agonists such as pramipexole and rotigotine have also been shown to be effective in treating RLS. However, augmentation is a common side-effect of dopaminergic treatment in patients with RLS. Augmentation has been defined as an early onset of symptoms of RLS during the day, an increase in severity of symptoms, and the involvement of other body parts. Augmentation usually resolves with cessation of the medication and can be kept to a minimum by keeping the dose low (61). $\alpha_{2} \delta$ calcium channel ligands such as gabapentin and pregabalin have been proven to be effective for treatment of RLS for short- and long-term use. Opioids, preferably oxycodone, are efficacious for RLS, but evidence is insufficient to make recommendations for long-term treatment (62). Recent treatment guidelines recommend oral iron therapy for persons with RLS and low serum ferritin; the limit for serum ferritin for starting iron therapy ranges from $<50 \mathrm{mcg} / \mathrm{L}$ to $<75 \mathrm{mcg} / \mathrm{L}(62-65)$. Intermittent use of benzodiazepines or benzodiazepine receptor agonists before sleep may be useful for short-time use, especially if the patient has another cause of poor sleep (64).

The prevalence of RLS during pregnancy appears to be approximately 2-3 times higher than in non-pregnant women (66). Why RLS increases during pregnancy is not fully understood. Since iron supplies decrease during pregnancy, an association with iron deficiency could be possible and has been reported (67). However, this hypothesis is contradicted by the fact that RLS symptoms mostly disappear soon after delivery (68) whereas the iron deficiency persists. The levels of estrogens rise and fall almost simultaneously with the development of RLS 


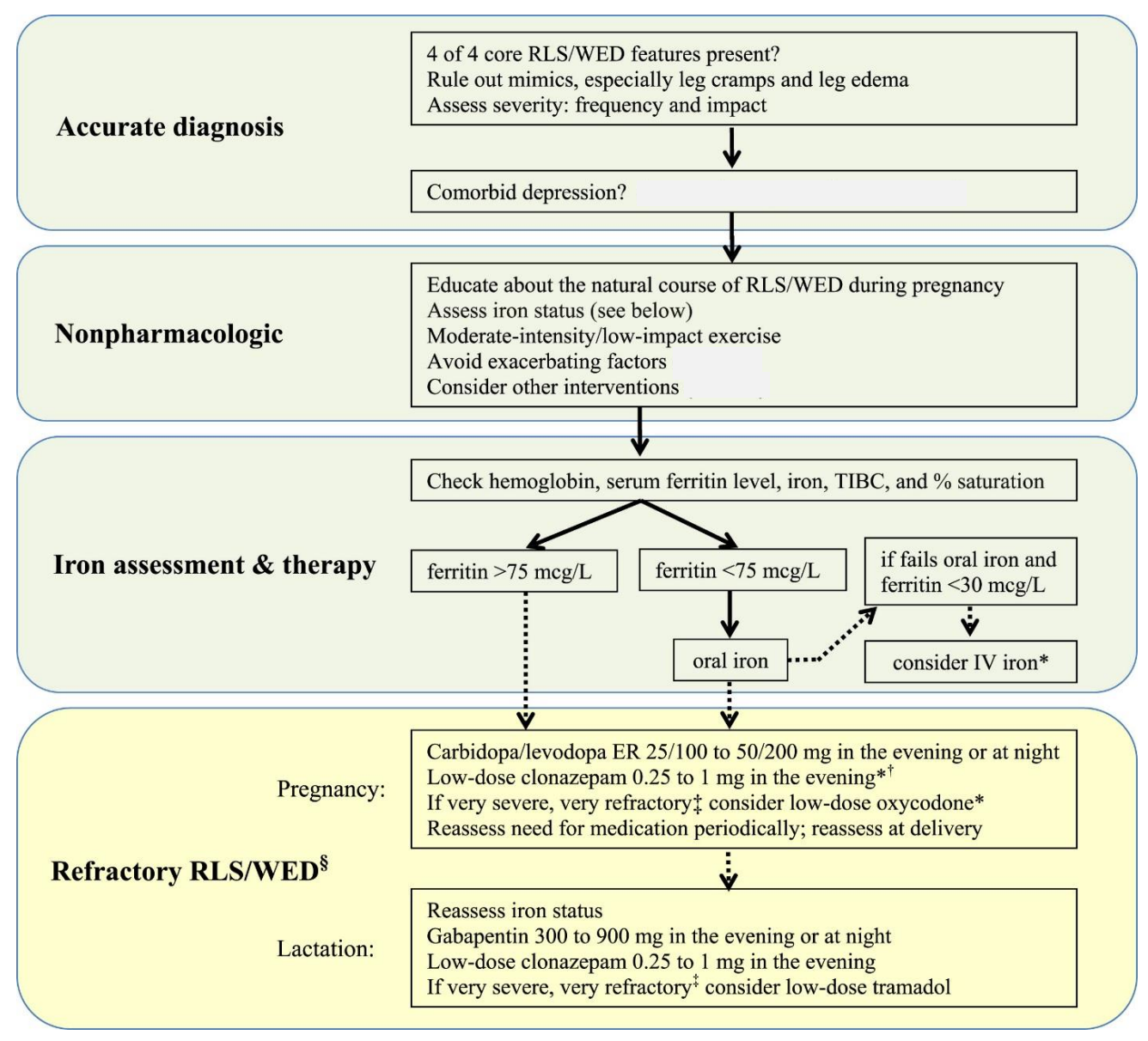

Algorithm for the diagnosis and management of RLS/WED during pregnancy and lactation. Dotted arrows: proceed only after assessment of severity, risks, and benefits by provider and patient.

*After $1^{\text {s}}$ t trimester. $\uparrow$ Avoid concurrent use with diphenhydramine or anticonvulsants. ${ }^{\S}$ Refractory: an inadequate response to at least one nonpharmacologic intervention and iron (if ferritin $<75 \mathrm{mcg} / \mathrm{L}$ ), tried over an adequate period of time. $\neq$ Very severe, very refractory: a score of $>30$ on the International RLS Study Group rating scale and failure to respond to at least one nonpharmacologic treatment, iron (if ferritin $<75 \mathrm{mcg} / \mathrm{L}$ ), and one non-opioid pharmacologic treatment.

Figure 2. Clinical practice guidelines for the diagnosis and treatment of restless legs syndrome during pregnancy and lactation recommended by the International RLS Study Group 2014.

Reprinted from Sleep Medicine Reviews (2014), http://dx.doi.org/10.1016/j.smrv.2014.10.009 Picchietti DL, Hensley JG, Bainbridge JL, Lee KA, Manconi M, McGregor JA, et al. Consensus clinical practice guidelines for the diagnosis and treatment of restless legs syndrome/Willis-Ekbom disease during pregnancy and lactation, with permission from Elsevier. 
during pregnancy, and there are studies showing that women with RLS have higher serum concentrations of estrogen than women without RLS (3), but there are also contradicting data (67). There are studies showing an association between RLS and adverse pregnancy outcomes such as increased rates of preeclampsia, cesarean delivery, and depressed mood, but data are limited (69-71). Recently a committee from the International RLS Study Group has published clinical practice guidelines for the diagnosis and treatment of RLS during pregnancy and lactation (72). A summary of the guidelines is shown in Figure 2. The authors especially point out the importance of correct diagnosis for RLS during pregnancy.

\section{Postpartum depression}

Postpartum (or postnatal) depression (PPD) is a major depression in the postpartum period. ICD-10 (International Statistical Classification of Diseases and Related Health Problems 10th Revision) defines PPD as a depressive episode commencing within six weeks after delivery, but often depression developing within the first year after delivery is considered as PPD.

A clinical depression is distinguished by lowering of mood, reduction of energy, and decrease in activity. Capacity for enjoyment, interest, and concentration is reduced, and marked fatigue after even minimum effort is common. Self-esteem and self-confidence are almost always reduced and, even in the mild form, some ideas of guilt or worthlessness are often present. The lowered mood varies little from day to day, is unresponsive to circumstances and may be accompanied by so-called "somatic" symptoms such as loss of interest and pleasurable feelings, marked psychomotor retardation, agitation, loss of appetite, weight loss, and loss of libido. Suicidal ideation (active or passive) might also be present.

The prevalence of PPD was $13 \%$ in a Swedish survey (73). Known risk factors for developing PPD are stressful life events during pregnancy or after delivery, pregnancy or delivery complications, depression earlier in life and lack of social support $(74,75)$. The huge endocrine changes following delivery and breast feeding are also thought to be of great importance (76). There are also immunological theories for the development of PPD (77). The symptoms of PPD are the same as those of a major depression. However, up to 60 percent of women with PPD have obsessive thoughts focusing on aggression toward the infant (78). 
The consequences of depression in the postnatal period can be harmful for both mother and child, since they affect the mother-child relationship, the mother's self-esteem and her social and personal adjustment to her new role. PPD has also been shown to impact cognitive and emotional development of the child $(79,80)$. Individual or group psychotherapy is an effective treatment for mild to moderate postpartum major depression (81). Selective serotonin reuptake inhibitors have become the mainstay of treatment for moderate to severe postpartum major depression (82) and can be used during breastfeeding (83). The importance of identification of mothers at risk for developing PPD has been highlighted in a recent Cochrane review, which states that psychosocial and psychological interventions significantly reduce the number of women who develop postpartum depression (84).

Sleep and depression are closely related. It is known that up to $90 \%$ of all persons suffering from major depression have subjective sleep disturbances (85). Depressed persons display impaired sleep continuity, disinhibition of REM sleep and decrease of slow wave sleep on electroencephalogram during sleep $(86,87)$. There is evidence that associations between sleep and depressed mood also are affected by women's reproductive state (88). Sleep disturbances are often part of the symptoms of depression, but there is also evidence that sleep alterations precede the onset of depression (89-91). This relationship between sleep and depression can also be present before, during, and after pregnancy. Associations between disturbed sleep during pregnancy and antenatal depression or depressive symptoms have been shown (92-94). In a large Norwegian study an association between poor sleep quality after delivery and PPD was also found. (95). A few studies have investigated PPD and sleep during pregnancy, but the results are divergent and possibly, but not necessarily, may result because different methods for measuring sleep-associated factors were used in different studies (96-100). There is also some evidence that subjective perception of sleep, more than objective sleep quality, is associated with PPD symptoms $(101,102)$. 


\section{Adverse outcomes of pregnancy with possible association with sleep disorders}

Several adverse obstetric outcomes have been reported in association with sleep disorders (103-105). One of the most investigated outcomes comprises different forms of gestational hypertension, mainly because sleep disturbances in terms of OSA are known to cause hypertension in a normal population.

Hypertension is present in $8 \%$ of all pregnant women, $2 \%$ as chronic hypertension, $3 \%$ as gestational hypertension and $3 \%$ as preeclampsia (106). Chronic hypertension is defined as a blood pressure $\geq 140 / 90$ before gestational week 20. Gestational hypertension is diagnosed if blood pressure $\geq 140 / 90$ after gestational week 20 in a previously normotensive woman. The diagnosis of preeclampsia requires additional leakage of protein to urine $\geq 0.3$ gram $/ 24$ hours according to the ICD-10 criteria (107). Preeclampsia is feared by obstetricians since it can develop into a life threatening condition for the pregnant woman with seizures/eclampsia, hemolysis, highly impaired coagulation and multi organ failure. Preeclampsia can also impact the fetus, chiefly by causing growth retardation and prematurity (108). The risk of developing preeclampsia is highest in the first pregnancy, but women who have had preeclampsia in their first pregnancy have an increased risk of recurrence in future pregnancies (109). Other known risk factors for developing preeclampsia are chronic hypertension, chronic renal disease, family history of preeclampsia, antiphospholipid syndrome, twin pregnancy and age $>40$ years (108). Preeclampsia is considered as an immunologic disease but the exact cause is not fully understood (110).

There are also studies showing an association between sleep and gestational diabetes, preterm birth (before gestational week 37) and cesarean section. Delivery of low birth weight infants and newborns with Apgar score $<7$ at 5 minutes age have also been reported in association with impaired sleep (103-105). 


\section{Specific background of the studies in the thesis}

In the year 2000, a Swedish study was published showing a retrospective association between snoring in the last trimester of pregnancy and development of gestational hypertension and growth retardation of the fetus (111). This was the first study demonstrating such a connection and it has been cited frequently. Since snoring is often a symptom of OSA, and OSA via activation of the sympathetic and parasympathetic nervous systems contributes to development of hypertension in a normal population, the theory behind these findings was that snoring might also be a part of the explanation for development of hypertension during pregnancy.

The primary aim of the research leading to this thesis was to check the results of that retrospective Swedish study in a prospective set-up. The secondary aim was to objectively assess if snoring during pregnancy was associated with OSA.

A study design with the same number of pregnant women (500) as in the Swedish retrospective study was set up. The women, who were included in early pregnancy, were to be given a questionnaire in every trimester of pregnancy and also on one occasion after giving birth. Women who snored were asked to undergo a nocturnal sleep recording. Due to high drop-out ratio this part of the study was later replaced by objective sleep apnea recordings in 100 healthy pregnant women and 80 non-pregnant controls.

Furthermore, the nature of this prospectively collected material made it possible to evaluate the development of various sleep disorders during the course of pregnancy. The association of these disorders with several conditions connected to sleep and pregnancy was also investigated. 


\section{Aims}

The aims of the included studies were to investigate:

- The development of snoring during pregnancy and whether snoring during pregnancy is associated with increased daytime sleepiness or adverse pregnancy outcomes (Paper I).

- The development of restless legs syndrome (RLS) during and after pregnancy, and whether RLS is associated with snoring or other pregnancy-related symptoms (Paper II).

- $\quad$ The possible association between depressive symptoms in the postpartum period and sleep-related problems during pregnancy, using screening instruments (Paper III).

- The possible differences between pregnant and non-pregnant women concerning objectively recorded sleep disordered breathing and daytime sleepiness as measured by the Epworth Sleepiness Scale (Paper IV). 


\section{Material and methods}

\section{Participants}

\section{Cohort 1, paper I-III}

The Swedish antenatal health care system reaches almost $100 \%$ of all pregnant women and both the antenatal and delivery care are free of charge. At the antenatal care clinics (ACC), healthy pregnant women are advised to attend the regular antenatal program with seven to nine visits to a midwife, and, if needed, extra appointments with an obstetrician and/or with the midwife. The first visit generally takes place around gestational week $10-12$ (112).

Between March 2006 and March 2007 women attending their first visit at the ACC at the outpatient unit at the University hospital in Linköping, Sweden, were asked to participate in a study of sleep during pregnancy. Women who had diabetes mellitus, any known neurological disease, drug abuse, poor knowledge of the Swedish language or were on medication against hypertension were excluded from participation. After receiving printed and oral information 500 women gave their written consent for participation in the study. These women were given a questionnaire, described below, at three regular visits at the ACC in the $1^{\text {st }}, 2^{\text {nd }}$ and $3^{\text {rd }}$ trimester. The women also authorized the researchers to have full access to information in the women's obstetrical medical records.

The number of participating women and drop-outs is displayed in Figure 3. Five hundred women were included. However, one of the included women turned out to have chronic hypertension and was therefore later excluded. She was unfortunately included in the statistical analyses for paper II, but in no other analyses. She answered the two first questionnaires and stated that she was a habitual snorer from $2^{\text {nd }}$ trimester and also suffered from RLS. She had a preterm delivery in gestational week 24 , due to severe preeclampsia. The causes of the drop-outs are shown in Table 1. The women who dropped out after inclusion did not differ from the others regarding BMI, age, parity or prevalence of habitual snoring or BMI. Analysis of women who chose not to participate has not been made since the documentation about who was asked to participate and who was not was fragmentary. 


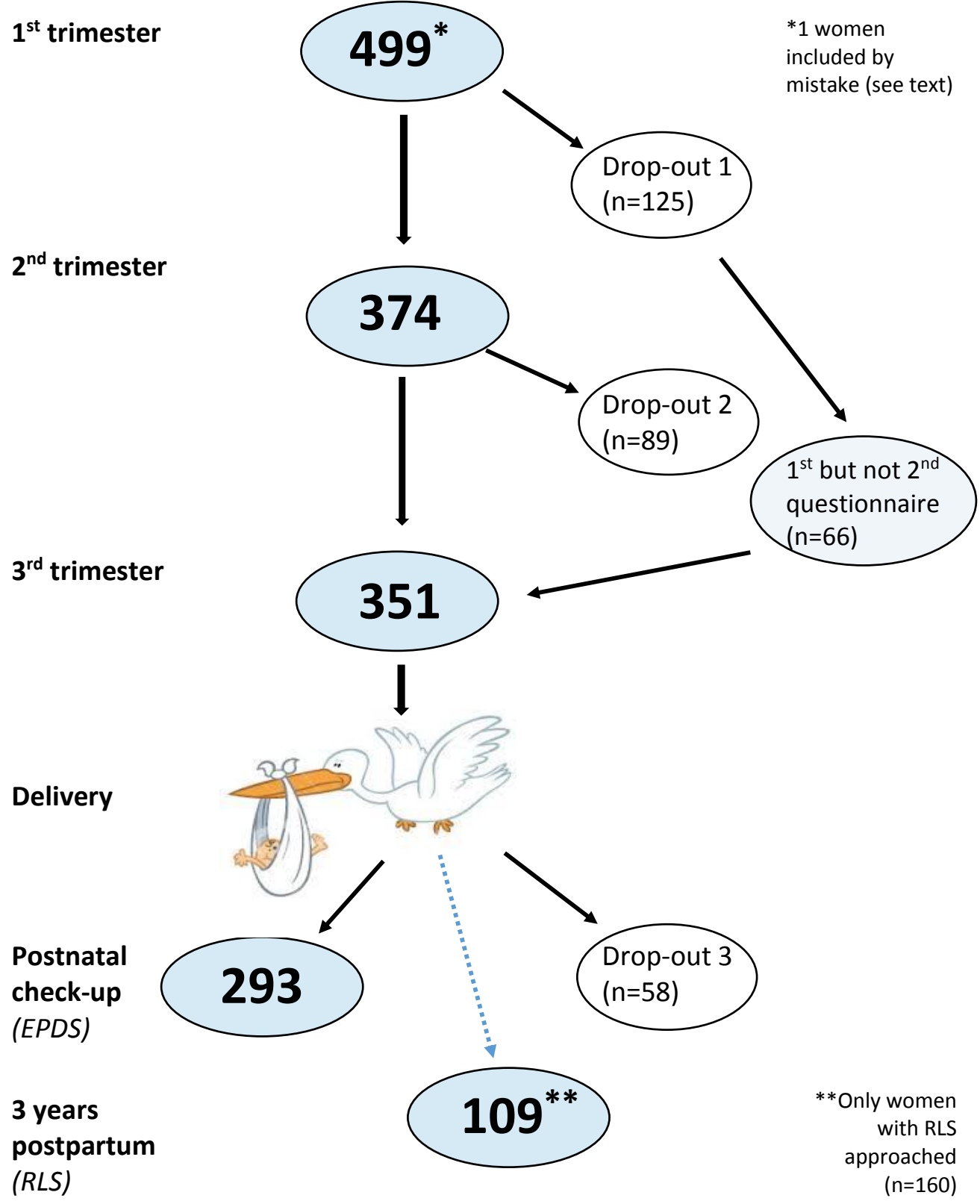

Figure 3. Flowchart for participating women in cohort 1. All three questionnaires given during pregnancy were answered by 285 women. 


\begin{tabular}{|l|c|c|c|}
\hline & \multicolumn{1}{c}{$\begin{array}{c}\text { Drop-out 1 } \\
\text { Between } 1^{\text {st }} \text { and } \\
2^{\text {nd }} \text { trimester }\end{array}$} & $\begin{array}{c}\text { Drop-out 2 } \\
\text { Between 2 } \\
3^{\text {nd }} \text { trimester }\end{array}$ & $\begin{array}{c}\text { Drop-out 3 } \\
\text { Between 3 } \text { rd }^{\text {rd }} \text { trimester } \\
\text { and postpartum check-up }\end{array}$ \\
\hline \hline $\begin{array}{l}\text { Miscarriage or } \\
\text { preterm delivery }\end{array}$ & 11 & 12 & \\
\hline Moving to other city & 4 & 2 & 38 \\
\hline Unknown reason & 110 & 75 & 18 \\
\hline $\begin{array}{l}\text { Absence from } \\
\text { postpartum check-up }\end{array}$ & & & 2 \\
\hline Other & & & 58 \\
\hline Total & 125 & 89 & \\
\hline
\end{tabular}

${ }^{+}$Death of neonate or PPD diagnosed before postpartum check-up.

Table 1. Causes of drop-outs, cohort 1.

Only women who had answered the questionnaire in the $3^{\text {rd }}$ trimester were included in the analyses of EPDS at postpartum check-up. The follow-up three years after delivery consisted of a questionnaire concerning RLS, sent by mail, and only women who had stated RLS-symptoms during pregnancy $(n=160)$ were approached.

\section{Cohort 2, paper IV}

During 2009, pregnant women under care at the ACC in Linköping were asked to participate in a study that would require undergoing a respiratory recording during one night in late $2^{\text {nd }}$ or early $3^{\text {rd }}$ trimester of pregnancy. Women who had diabetes mellitus or had difficulties in understanding the Swedish language were excluded. One hundred women in gestational week 24-34 were recruited and gave their written consent for participation. This consent included authorizing the researchers to have full access to the women's current obstetric records. These women were given an extra appointment in the $3^{\text {rd }}$ or late $2^{\text {nd }}$ trimester of pregnancy, at which they were asked to fill out a questionnaire about their sleep (described below). On the following night a polygraphic respiratory recording was made in their homes.

In 2014 and the beginning of 2015, age- and BMI-matched controls were recruited from healthy volunteers. The pregnant women had been divided into four groups based on their age and BMI and the controls were recruited in order to reach the same proportions as the pregnant women. The women in the control group had to meet the same exclusion criteria as the pregnant women as well as not being pregnant. They answered the same questionnaire and their blood 
pressure, weight and length were measured before the nocturnal respiratory recordings were done. Eighty controls were recruited.

All participants were given printed as well as oral information before giving informed consent.

Of the 100 pregnant women, 88 completed the questionnaire. Six of the 100 respiratory recordings could not be scored due to technical problems. All 80 controls completed the questionnaire. In four cases $(5 \%)$ the respiratory recordings could not be scored for the same reasons as above.

\section{Questionnaires}

All participants were given the same questionnaire (the original questionnaire in Swedish is enclosed as Appendix 1). The women were asked to rate their experience of snoring, apneas during sleep, morning fatigue and daytime sleepiness by answering the questions "Do you snore?" "Has anyone told you that you have breathing pauses during sleep?", "Do you feel tired and badly rested when you wake up at morning?" and "Do you feel sleepy during the day?" using the alternatives "always", "often", "sometimes", "seldom", "never" or " I don't know" on a daily basis. The women who answered "often" or "always" on these questions were identified as suffering from "habitual snoring", "nocturnal apneas", "morning fatigue" and "daytime sleepiness" respectively. The questionnaire also included the four questions for diagnosing RLS set by the International RLS Study Group (Box 2, page 17) and the Epworth Sleepiness Scale (described below). Pregnant women also answered a question about edema experienced in hands, legs or feet and the answers were rated as "none", "mild", "moderate" or "severe" edema.

The women in cohort 1 answered an identical questionnaire in the $1^{\text {st }}, 2^{\text {nd }}$ and $3^{\text {rd }}$ trimesters of pregnancy. The same questionnaire was given the women in cohort 2 and the controls on one occasion just before the nocturnal respiratory recording.

The women were categorized on the basis of their answers in the questionnaires. The women studied for paper I who stated that they were already snoring early in pregnancy were assumed to have been snorers even before pregnancy. Therefore they were assigned to the group "habitual snorers". Women who stated that they 
had only started to snore after $1^{\text {st }}$ trimester we assigned to the group "gestational snorers", given that name because their snoring was thought to have been caused by the pregnancy itself. Women who stated that they did not snore at all were called "non-snorers". We changed the nomenclature in papers II-IV, where the term "habitual snorers" is used for all women who stated that they snored often or always. No consideration was given to when they started to snore. Women who answered "yes" to the first three questions concerning RLS (Box 2, page 17) and stated that they had the symptoms at least once per month were identified as suffering from RLS.

All women in cohort 1 who reported symptoms of RLS during their pregnancy were sent an additional questionnaire by mail three years after childbirth. This was a shorter questionnaire than the one used during pregnancy. The women were asked if they were pregnant when answering the questionnaire, the date of their last delivery, if they still suffered from RLS symptoms and, if not, when the symptoms had disappeared.

\section{Epworth Sleepiness Scale}

The Epworth Sleepiness Scale (ESS) (113) is one of the most wide-spread inventories used to assess subjective daytime sleepiness over time. The respondent is asked to rate the risk of falling asleep on a four-point Likert scale $(0-3$ points, where 0 indicates no risk of falling asleep) in eight different situations, shown in Box 3 . Maximum score is 24. When interpreting the ESS score a total score below 10 points is often considered normal; anyone with a score $\geq 10$ is said to suffer from excessive daytime sleepiness (EDS). The ESS has been validated for use in pregnancy (114). However, current research indicates that gender and

\section{Epworth Sleepiness Scale}

1. Sitting and Reading

2. Watching Television

3. Sitting inactive in a public place, for example, a theater or a meeting

4. As a passenger in a car for an hour without a break

5. Lying down to rest in the afternoon

6. Sitting and talking to someone

7. Sitting quietly after lunch when you've had no alcohol

8. In a car while stopped in traffic

Chances of dozing:

0 : Never

1: Slight chance

2: Moderate chance

3: High chance

Score: 0-9 normal; 10-12 mild sleepiness; 13-17 moderate sleepiness; 18 , and above severe sleepiness

Box 3. The situations given in the Epworth Sleepiness Scale, and the set answers. By M.W. Johns, 1991. 
age may impact the separate items of the ESS score (115).

\section{Edinburgh Postnatal Depression Scale}

All women attending the ACC were asked to fill out the Edinburgh Postnatal Depression Scale (EPDS) as part of the routine postpartum check-up visit usually occurring 6-12 weeks after giving birth. EPDS is a widely used and validated screening instrument specifically designed for detecting PPD (116-118). It consists of a 10 item self-report scale measuring common symptoms of depression. Each item is scored on a four point scale (0-3) and rates the intensity of depressive symptoms during the previous seven days. The maximum score is 30. The ten questions of the EPDS are displayed in Box 4 and the full Swedish version of the EPDS is attached as Appendix 2. In order to find all actual major depressions, Cox et al. proposed a cut-off level $\geq 10$ to reduce detection failure in the postpartum period (116). Therefore, this cut-off level was used. The total EPDS score from the postpartum check-up of all women in cohort 1 was obtained from the obstetric medical records.

\section{Medical and social data}

Data concerning relevant medical and social data for the pregnant women were taken from the Swedish standardized antenatal and delivery records. Age, parity, body mass index (BMI) at first visit, blood pressure, preeclampsia, gestational hypertension, twin pregnancy, gestational week at delivery, birth weight, Apgar

\section{Edinburgh Postnatal Depression Scale}

1. I have been able to laugh and see the funny side of things.

2. I have looked forward with enjoyment to things.

3. I have blamed myself unnecessarily when things went wrong.

4. I have been anxious or worried for no good reason.

5. I have felt scared or panicky for not very good reason.

6. Things have been getting on top of me.

7. I have been so unhappy that I have had difficulty sleeping.

8. I have felt sad or miserable.

9. I have been so unhappy that I have been crying.

10. The thought of harming myself has occurred to me.

Box 4. Questions of the Edinburgh Postnatal Depression Scale, set by J.L. Cox et al in 1997. 
score at 5 minutes and gender of child were analyzed in all papers. For evaluation of RLS (paper II), weight gain between the first visit and the $3^{\text {rd }}$ trimester, iron and folate intake during pregnancy and hemoglobin levels were also analyzed. When investigating snoring (paper I) marital status, mode of delivery and complications associated with delivery were also evaluated. In paper III additional data known for association with PPD were extracted from the records: occupation, use of alcohol, illegal drugs or tobacco, prior PPD, current depressive disorder, medication, intercurrent somatic disease, stressful life events during current pregnancy, number of appointments to obstetric medical staff during pregnancy and stated fear of delivery. For classification of occupations the ISCO -88 system (119) was used for dividing the occupations into two skill levels. Women who did not fit into one of these groups (students, unemployed or on permanent sick leave) were referred to as a third group.

\section{Nocturnal respiratory recordings}

The gold standard for sleep recordings is the so called polysomnography (PSG), which must comprise at least EEG (electroencephalography), EOG (electrooculography) and submental EMG (electromyography), in order to enable scoring of exact sleep time and all sleep stages. Depending on the diagnostic question, a number of other parameters can be added, e.g., EMG from leg muscles, ECG (electrocardiography), different measurements of respiration and body position. Polysomnography is used for diagnosis a wide spectrum of sleep disorders: SDB and OSA, narcolepsy, complicated parasomnias (e.g. sleep waking, REM sleep behavior disorders, night terrors), nocturnal seizures and periodic limb movements disorder (PLMD).

However, when diagnosing SDB, not all information from a PSG is required. PSG is a resource-demanding investigation, as EEG scoring is time consuming and requires expensive equipment and specially trained technicians for application of the electrodes. It is also possible that the investigation itself might impact sleep, for example position in bed, which in turn might impact the prevalence of obstructive events since they are more common in supine position (120). This has led to development of a wide range of portable monitoring devices that measure from one to several physiologic parameters. These have been used as substitutes for standard overnight polysomnography to assess patients with suspected OSA. Advantages of portable monitoring over standard overnight polysomnography 


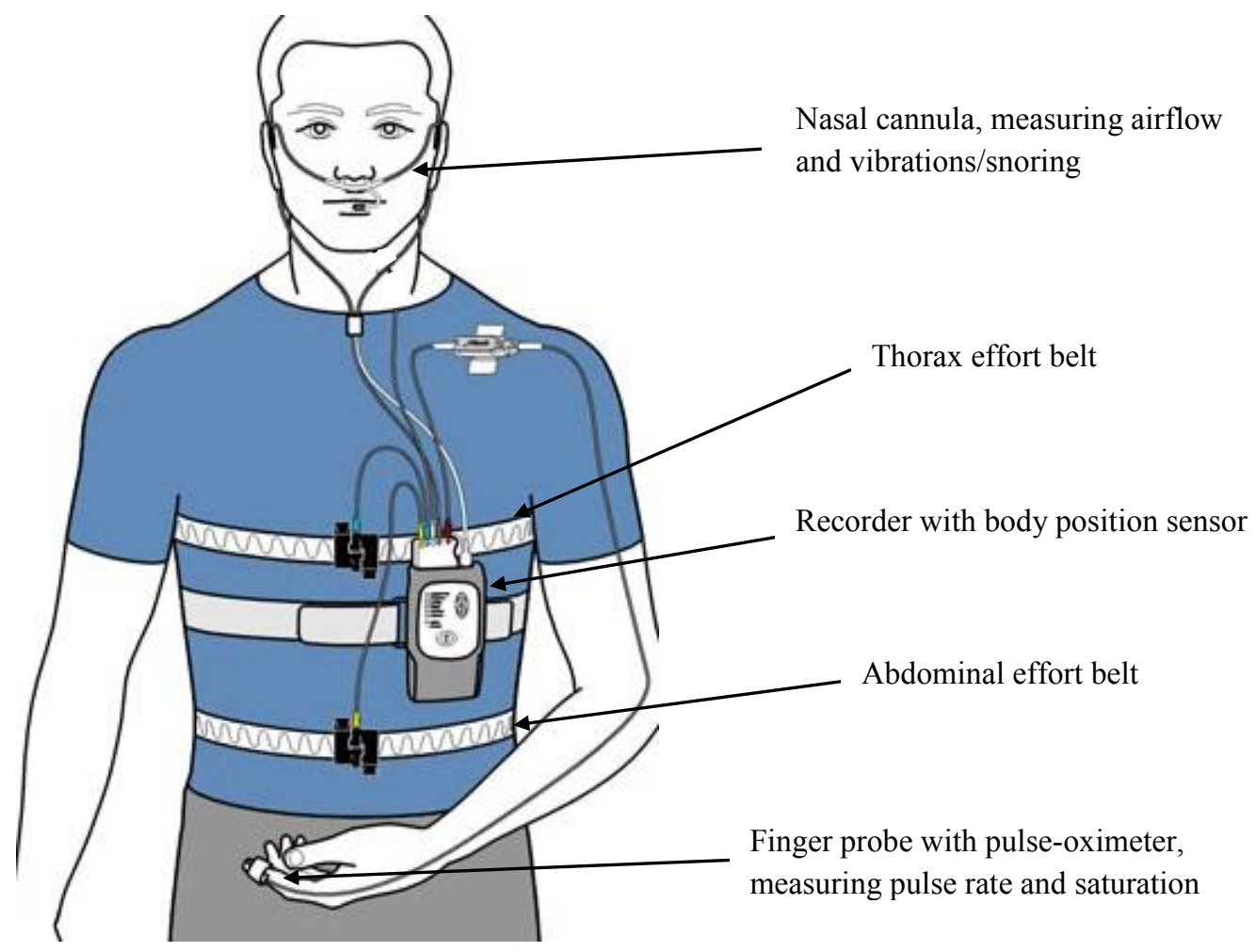

Figure 4. Configuration of the Embletta recording device.

include greater convenience and accessibility for patients, and lesser cost. Limitations of portable monitoring include the absence of a trained sleep technologist to correct any technical difficulties and to attend to any patient needs during the test as well as no knowledge of the actual sleeping time, implying a risk of over- or underestimating the index-values (all calculated as average number of events per hour of sleep). Still, similar results in terms of AHI compared to polysomnography have been reported $(121,122)$. American Academy of Sleep Medicine (AASM) has developed recommendations for unattended portable monitoring for the diagnosis of OSA (123), where they state that it should be performed only in conjunction with a comprehensive sleep evaluation.

In our studies, the Embletta portable diagnostic system (Natus Europe GmbH, Planegg, Germany) was used for the nocturnal respiratory recordings. The Embletta device records nasal airflow (air pressure), abdominal and thoracic 


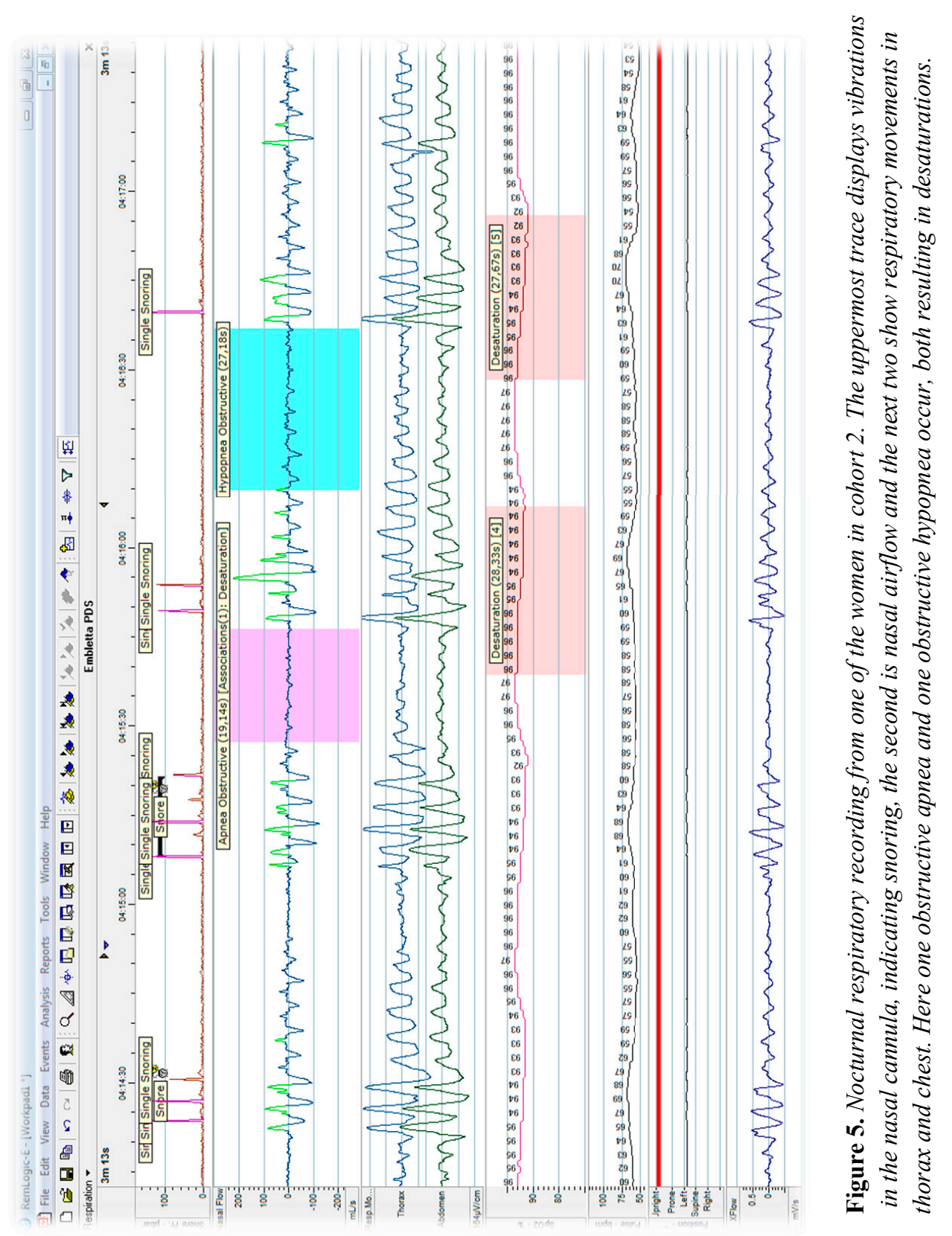


respiratory movements, snoring (vibrations in airflow), body position, oxygen saturation and heart rate (pulse oximetry, finger probe). All recordings were conducted in the women's homes. The equipment was put in place by the woman herself after instructions given at the sleep clinic (Figure 4).

In interpreting our sleep apnea recordings, apnea was defined as cessation in airflow for 10 seconds, and obstructive, central and mixed events were scored separately. Hypopnea was defined as $\geq 50 \%$ reduction in tidal volume for 10 seconds or more followed by a desaturation of $4 \%$ or more. OSA was defined as total AHI of $\geq 5$. The oxygen desaturation index (ODI) was calculated as the average number of $\geq 4 \%$ drops in saturation per hour of estimated sleep. A minimum estimated sleep time of four hours was required for analysis. Sleeping time was estimated from body and respiration movements. The software RemLogic 3.2 was used for scoring of the recordings. The same physician manually scored all recordings and deleted artefacts in airflow and oximetry (mostly due to movements). An example of a respiratory recording from our study is shown as Figure 5.

\section{Statistics}

\section{Cohort 1}

Characteristics of the pregnant women were presented as mean and standard deviation (SD) for continuous variables and as numbers and percentages for discrete variables. The $t$ test was used for comparing mean values and binary variables and the Pearson $\chi^{2}$ test was used for categorized variables when comparing two groups. In paper I comparisons between non-snorers, gestational snorers and habitual snorers were conducted using one-way analysis of variance (ANOVA) for continuous and binary variables. For evaluation of differences in prevalence of RLS between the three trimesters in paper II, Z-test, with p-values Bonferroni corrected for multiple comparisons, was used. Differences between the proportions between women with and without experienced RLS concerning the severity trend of snoring (from never/seldom to always), were tested with Mantel-Haenszel linear-by-linear association chi-squared test.

In paper III single and multiple logistic regression was used for comparing women with high versus normal EPDS score for possible risk factors. EPDS groups (normal or high score) were used as the dependent variable and possible 
risk factors. Data were adjusted for sociodemographic background data and for variables identified as significant risk factors for a high EPDS score. Pearson Product Moment Correlation was used for calculation correlation between different variables for measuring of sleepiness. The significance level was set to $5 \%$ (two-sided) in all tests.

\section{Cohort 2}

The material in paper IV was checked for normal distribution using one-sample Kolmogorov-Smirnov test. Since it was not proven to be normally distributed, the Mann Whitney U test was used to test for dependency for continuous variables. Pearson's chi square test was used for dichotomized variables.

For analyzing differences regarding the separate items in the ESS ordinal regression differential item functioning (DIF) analyses were used. This was performed in two steps. In the first step, the item score was used as the dependent variable, and the total test score was used as the independent variable. Then, the grouping variable (pregnant or control and habitual snorer or non-snorer respectively) was added as an independent variable, each variable modelled separately. If the grouping variable is significantly related to the item score, when potential between-group differences in total score are taken into account, the item is said to exhibit DIF with regard to the grouping variable. This was, however, not used in our study since no significance was found between grouping variable and item score.

The significance level was set to 5\% (two-sided) in all tests except in the DIF analyses where the p-value was adjusted due to multiple testing, and hence a $\mathrm{p}<0.006$ was considered statistically significant.

The statistical software IBM SPSS 15.0-22.0 (IBM SPSS Inc., Armonk, NY) was used for all statistics. 


\section{Ethical considerations}

The study was approved in 2005 by the Regional Ethical Review Board, Linköping, Sweden, no. M 97-05. For recruitment of the controls to cohort 2 a supplement was submitted and approved in 2013. When preparing the study, ethical questions and dilemmas were taken under consideration.

The questionnaires used concerning sleep are well established and not considered offensive or harmful in any way. Nocturnal respiratory recording is a routine investigation for suspected sleep disordered breathing, which might imply some discomfort for the woman, and in some cases disturbance of sleep. However, making the investigation at home makes the situation as nearly similar to an ordinary night as possible. The respiratory recording is non-invasive, not painful and does not carry any risks for the mother and the expected child. If OSA was detected in the study, the women were offered established treatment (CPAP). Since there was minimal/no risk of harm connected to participation in the study, the amount of benefit clearly outweighed the amount of risk for the individual woman.

The EPDS used at the postpartum check-up in order to screen for PPD includes questions about psychiatric and psychological well-being. There is always a possibility that questions about mental health may increase anxiety and create stress in sensitive women. However, the positive effects of paying attention to this problem and making women aware of depressive symptoms outweigh the disadvantages. Moreover, filling out the EPDS is part of the normal postpartum care and was not influenced by participation in our study. There are well established routines for taking care of women with high EPDS scores at the ACC in Linköping, depending on the total score and the answer given to question 10 (concerning suicidal thoughts). This routine includes a follow-up consultation, psychotherapy and/or referral to psychiatric units.

The main outcomes in our study, i.e., gestational hypertension, preeclampsia and postpartum depression, are connected to major risks in terms of physical and psychological complications for both mother and child. If a sleep disorder, many of which are both treatable and curable, was found to be one of the causes of these outcomes, this knowledge would be of benefit for all pregnant women. 
All information about the participants was coded according to Swedish law (124). In the printed information distributed to all women asked to participate in the study, it was clearly stated what the purpose of the study was, what participation would entail for the women, who was the head of the study, how the collected personal information was handled and who was responsible for this handling. It was also explained that participation or refraining would not impact the care to be given. Finally, it was explained that any woman, for any reason and without explanation could withdraw from participation. Written informed consent was collected from all participating women. 


\section{Results and comments}

\section{Participants}

The participants in cohort 1 and their response rate are shown in Figure 3, page 28 , and further explained in the material and method-section. Baseline data of cohort 1 are shown in Table 2.

Cohort 1 was handled differently in each of the original papers. In paper I results from the questionnaires from the $1^{\text {st }}$ and $3^{\text {rd }}$ trimesters were analyzed, and when analyzing development of snoring the 340 women who had answered the question about snoring at both occasions were included. In paper II data from all three questionnaires given during pregnancy $(n=500)$ were analyzed and the women who had RLS during their pregnancy $(\mathrm{n}=160)$ were also followed up after three years. In paper III only women who had answered the questionnaire in the $3^{\text {rd }}$ trimester and who had filled in the EPDS at the postpartum check-up were included $(n=293)$.

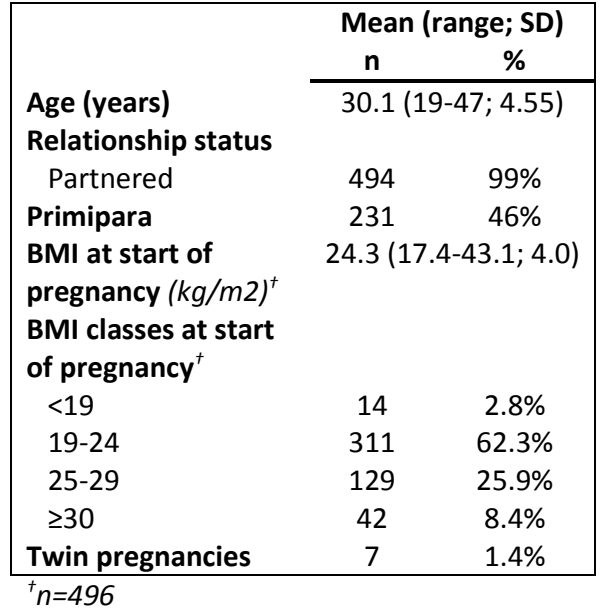

Table 2. Baseline data cohort $1(n=499)$.
In the results section below this division is not strictly followed. Instead the women who have answered all three questionnaires during pregnancy $(n=285)$ are used in most analyses concerning development of symptoms during pregnancy in order to facilitate comparison between different variables.

Cohort 2 is described in the material and method section on page 29 . Baseline data from cohort 2 and the controls are shown in Table 3. 


\begin{tabular}{|lccc|}
\hline & $\begin{array}{c}\text { Pregnant women }(\mathrm{n}=\mathbf{1 0 0}) \\
\text { Median }(\text { range; } 95 \% \mathrm{Cl}) \\
\mathrm{n}(\%)\end{array}$ & $\begin{array}{c}\text { Non-pregnant controls }(\mathrm{n}=\mathbf{8 0}) \\
\text { Median (range; 95\% Cl) }\end{array}$ & p value \\
\cline { 2 - 4 } & $31(23-42 ; 30-32)$ & $29(20-43 ; 27-31)$ & 0.080 \\
$\begin{array}{l}\text { BMe } \text { (years) }\left(\mathrm{kg} / \mathrm{m}^{2}\right) \\
\begin{array}{l}\text { Gest. week at } \\
\text { resp. recording }\end{array}\end{array}$ & $23.3(17.7-41.4 ; 22.8-24.1)$ & $22.6(17.4-33.0 ; 21.2-23.3)$ & 0.065 \\
\begin{tabular}{l} 
Primipara \\
\hline
\end{tabular} & $29(24-34 ; 28-29)$ & & \\
\hline
\end{tabular}

Table 3. Baseline data cohort 2 and controls.

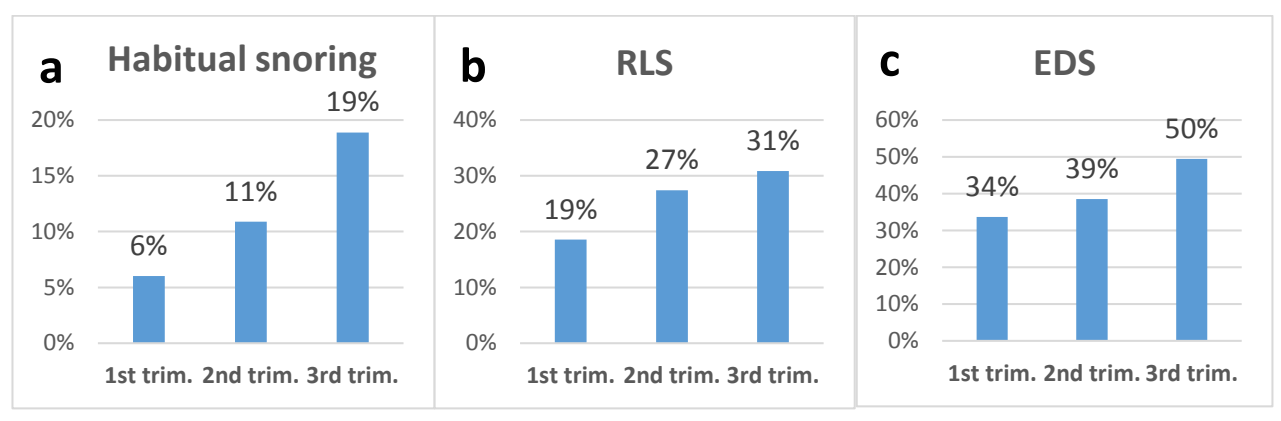

Figure 6. Development of habitual snoring, RLS and EDS (ESS $\geq 10)$ during pregnancy, $n=285$ (women who have answered all three questionnaires during pregnancy). The difference between trimesters is statistically significant for all items $(p<0.001)$.

\section{Subjective snoring}

The development of habitual snoring (subjectively snoring often or always) is shown in Figure 6a. In cohort 2, 15 of the pregnant women (17\%) were identified as habitual snorers from their questionnaires, compared to three (4\%) of the non-pregnant controls $(p=0.006)$.

In paper I we separated women who started to snore during pregnancy ("gestational snorers") from women who we assumed were already snoring before they became pregnant ("habitual snorers") and compared

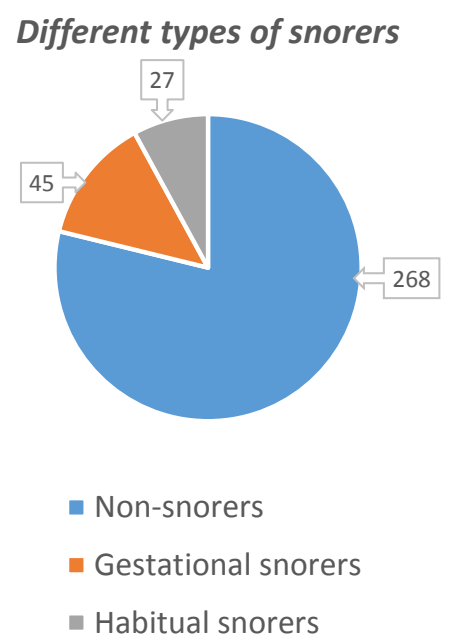

Figure 7. Distribution of different types of snorers in cohort $1(n=340)$. 
Table 4. Comparison between non-snorers, gestational snorers and habitual snorers $(n=340)$.

\begin{tabular}{|c|c|c|c|c|c|c|c|}
\hline \multirow{4}{*}{ BMI at start of pregnancy $(\mathrm{kg} / \mathrm{m} 2)$} & \multirow{2}{*}{\multicolumn{2}{|c|}{$\begin{array}{c}\begin{array}{c}\text { Non snorers } \\
(n=268)\end{array} \\
\text { mean/SD }\end{array}$}} & \multirow{2}{*}{\multicolumn{2}{|c|}{$\begin{array}{c}\begin{array}{c}\text { Gestational snorers } \\
(n=45)\end{array} \\
\text { mean/SD }\end{array}$}} & \multirow{2}{*}{\multicolumn{2}{|c|}{$\begin{array}{c}\text { Habitual snorers } \\
\begin{array}{c}(n=27) \\
\text { mean/SD }\end{array}\end{array}$}} & \multirow[b]{3}{*}{ p value } \\
\hline & & & & & & & \\
\hline & $\mathrm{n}$ & $\%$ & $\mathrm{n}$ & $\%$ & $\mathrm{n}$ & $\%$ & \\
\hline & \multicolumn{2}{|c|}{$23.6 / 3.8$} & \multicolumn{2}{|c|}{$24.4 / 3.3$} & \multicolumn{2}{|c|}{$26.4 / 5.0$} & $\begin{array}{l}0.381^{2} \\
0.001^{3} \\
0.098^{4}\end{array}$ \\
\hline BMI classes at start of pregnancy & & & & & & & $0.001^{5}$ \\
\hline$<19$ & 11 & 4.3 & 0 & 0.0 & 0 & 0.0 & \\
\hline $19-24$ & 183 & 71.8 & 27 & 60.0 & 9 & 33.3 & \\
\hline $25-29$ & 56 & 22.0 & 15 & 33.3 & 13 & 48.1 & \\
\hline$\geq 30$ & 15 & 5.9 & 3 & 6.7 & 5 & 18.5 & \\
\hline Weight gain $(\mathrm{kg})$ & \multicolumn{2}{|c|}{$10.4 / 3.4$} & \multicolumn{2}{|c|}{$11.5 / 3.8$} & \multicolumn{2}{|c|}{$11.2 / 3.9$} & $0.107^{1}$ \\
\hline \multicolumn{8}{|l|}{ Edema (moderate or severe) } \\
\hline $1^{\text {st }}$ trimester & 10 & 3.8 & 3 & 6.7 & 2 & 7.4 & $0.505^{1}$ \\
\hline \multirow[t]{3}{*}{$3^{\text {rd }}$ trimester } & 58 & 21.7 & 21 & 46.7 & 14 & 51.9 & $0.001^{2}$ \\
\hline & & & & & & & $0.002^{3}$ \\
\hline & & & & & & & $0.876^{4}$ \\
\hline \multicolumn{8}{|l|}{ Epworth Sleepiness Score } \\
\hline \multirow[t]{3}{*}{$1^{\text {st }}$ trimester } & \multirow{3}{*}{\multicolumn{2}{|c|}{$7.6 / 3.6$}} & \multirow{3}{*}{\multicolumn{2}{|c|}{$9.3 / 3.0$}} & \multirow{3}{*}{\multicolumn{2}{|c|}{$8.7 / 3.3$}} & $0.009^{2}$ \\
\hline & & & & & & & $0.264^{3}$ \\
\hline & & & & & & & $0.784^{4}$ \\
\hline \multirow[t]{3}{*}{$3^{\text {rd }}$ trimester } & \multirow{3}{*}{\multicolumn{2}{|c|}{$8.4 / 3.8$}} & \multirow{3}{*}{\multicolumn{2}{|c|}{$10.6 / 3.4$}} & \multirow{3}{*}{\multicolumn{2}{|c|}{$9.4 / 4.8$}} & $0.001^{2}$ \\
\hline & & & & & & & $0.388^{3}$ \\
\hline & & & & & & & $0.382^{4}$ \\
\hline \multicolumn{8}{|l|}{$\begin{array}{l}\text { Excessive Daytime Sleepiness } \\
(E S S \geq 10)\end{array}$} \\
\hline $1^{\text {st }}$ trimester & 81 & 30.2 & 17 & 37.8 & 9 & 33.3 & $0.589^{1}$ \\
\hline \multirow[t]{3}{*}{$3^{\text {rd }}$ trimester } & 112 & 41.8 & 32 & 71.1 & 12 & 44.4 & $0.001^{2}$ \\
\hline & & & & & & & $0.614^{3}$ \\
\hline & & & & & & & $0.267^{4}$ \\
\hline $\begin{array}{l}\text { Preeclampsia or gestational } \\
\text { hypertension }\end{array}$ & 7 & 2.6 & 2 & 4.4 & 1 & 3.7 & $0.775^{1}$ \\
\hline Normal vaginal delivery & 222 & 83.2 & 32 & 71.1 & 19 & 70.4 & $0.064^{1}$ \\
\hline
\end{tabular}

${ }^{1}$ One-way analysis of variance, ANOVA

${ }^{2}$ Post hoc analysis (Tukey): non snorers vs. gestational snorers

${ }^{3}$ Post hoc analysis (Tukey): non snorers vs. habitual snorers

${ }^{4}$ Post hoc analysis (Tukey): gestational snorers vs. habitual snorers

${ }^{5}$ Chi square test 
them to non-snoring pregnant women (proportions of groups showed in Figure 7). The three groups were compared regarding pregnancy data and some of the results are shown in Table 4 . The women who were already snoring in early pregnancy had significantly higher baseline BMI than the women who never snored, but snoring was not associated with the magnitude of weight gain during pregnancy. Snoring women were more likely to experience edema in late pregnancy than the non-snorers. Objectively stated, nocturnal apneas were very rare, only three women reported that they had apneas during sleep "often" or "always" at any stage of pregnancy.

\section{Nocturnal respiratory recordings}

Originally, some of the women from cohort 1 also underwent sleep recordings. Women who were classified as habitual snorers on the basis of their questionnaires were offered one night respiratory recording in the $3^{\text {rd }}$ trimester. However, the dropout rate was high and only 33 out of 86 (38\%) pregnant habitual snoring women chose to undergo the recording, which made it impossible to make a reliable interpretation of the data. Results from these recordings are shown in Figure 8. To be able to objectively assess if snoring during pregnancy was associated with OSA, and if SDB and OSA affected obstetric outcome, all women from cohort 2 underwent sleep apnea recording.
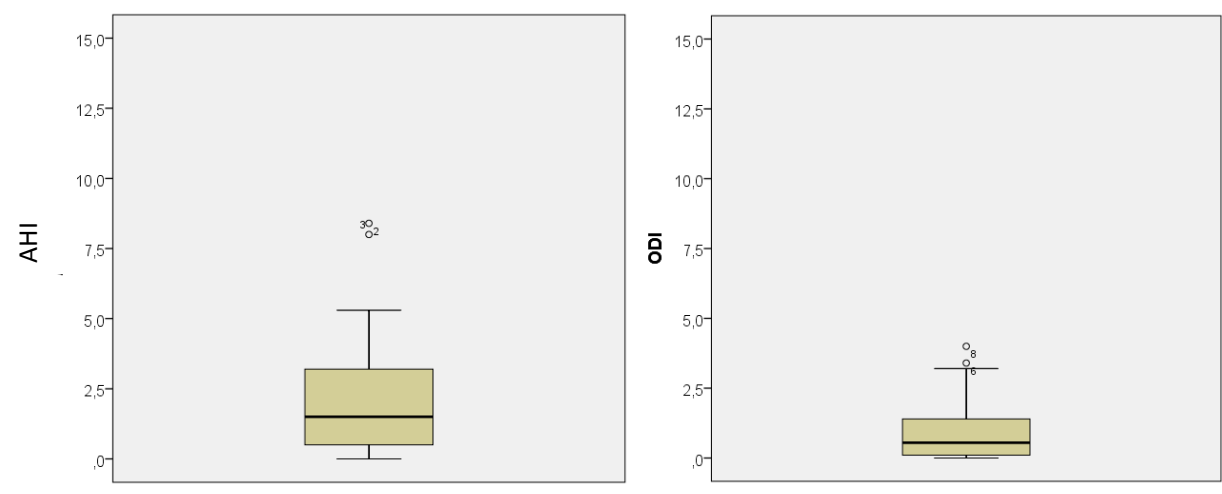

Figure 8. Distribution of AHI (apnea hypopnea index) and ODI (oxygen desaturation index) in sleep respiratory recordings in cohort $1(n=33)$. The "box" goes from the first quartile to the third quartile and the vertical line in the middle indicates the median of the data set. Values greater than the y-axis are not shown in the diagrams: one woman had total AHI 56.6, and one had ODI 47.0. 


\begin{tabular}{|lccc|}
\hline & $\begin{array}{c}\text { Pregnant women }(\mathrm{n}=94) \\
\text { Median (range; 95\% Cl) }\end{array}$ & $\begin{array}{c}\text { Non-pregnant controls } \\
(\mathrm{n}=76)\end{array}$ & \\
\cline { 2 - 4 } Measured snoring (\%) & $10(0-73 ; 5-11)$ & $2.5(0-53 ; 1-5)$ & $<0.001$ \\
AHI (events/hour) & $0.15(0-8.6 ; 0.0-0.5)$ & $0.0(0-8.0 ; 0.0-0.1)$ & 0.016 \\
ODI (events/hour) & $0(0-2.5 ; 0.0-0.0)$ & $0.1(0-9.1 ; 0.0-0.2)$ & 0.333 \\
Nadir SaO 2 (\%) & $93(81-97 ; 92-93)$ & $93(82-97 ; 93-94)$ & 0.034 \\
\hline
\end{tabular}

Table 5. Results from the respiratory recordings, cohort 2.

\begin{tabular}{|cccccc|}
\hline Pregnant & $\begin{array}{c}\text { Objective } \\
\text { snoring }\end{array}$ & $\begin{array}{c}\text { Measured } \\
\text { snoring }\end{array}$ & $\begin{array}{c}\text { AHI } \\
\text { (events/hour) }\end{array}$ & $\begin{array}{c}\text { ODI } \\
\text { (events/hour) }\end{array}$ & Nadir SaO $_{2}$ \\
\hline \hline yes & yes & $45 \%$ & 6.5 & 1.0 & $87 \%$ \\
no & yes & $11 \%$ & 8.0 & 9.1 & $89 \%$ \\
no & no & $16 \%$ & 5.8 & 5.8 & $82 \%$ \\
\hline
\end{tabular}

Table 6. Nocturnal respiration in the three women with OSA, cohort 2.

Ninety-four pregnant women from cohort 2 and 76 controls underwent nocturnal respiratory recordings that could be scored satisfactorily. The results are shown in Table 5. Small but statistically significant differences between the groups were found regarding measured percentage of snoring, $\mathrm{AHI}$ and nadir $\mathrm{Sa}_{2}$, but not regarding ODI. However, a low prevalence of OSA was found both in pregnant women and controls. Only four women, two pregnant women and two controls, had a total $\mathrm{AHI} \geq 5$. One of the pregnant women had predominantly central events and only three were therefore diagnosed with OSA, giving a prevalence of OSA of $1 \%$ in the pregnant women and $3 \%$ in the controls. More data about the three women with OSA are shown in Table 6.

In cohort 2, sleep recordings of the subjective habitual snorers versus the nonsnorers, showed no significant differences except concerning percentage of snoring (median $11 \%$ range $1-45 \%, 95 \%$ CI $5.3-14.0 \%$ vs $4.5 \%$ range $0-73 \%$, $95 \% \mathrm{CI} 2.4-6.2 \% \mathrm{p}=0.033$ ). This makes it unlikely that snoring during pregnancy is a symptom of SDB or OSA. 


\section{Restless Legs Syndrome}

The development of RLS during pregnancy is shown in Figure 6b, page 42. No associations between RLS and anemia, parity, body mass index, weight gain or experienced edema were found. However, women who snored in the $1^{\text {st }}$ or $2^{\text {nd }}$ trimester of pregnancy had a higher prevalence of RLS in the $3^{\text {rd }}$ trimester. This was shown by using chi-squared test for trends; statistics are shown in Table 7. This indicates that snoring in early pregnancy might predict RLS later.

Among the women who experienced RLS during pregnancy ( $\mathrm{n}=160) 109$ (68\%) answered the questionnaire about RLS that was mailed to them three years after giving birth. Nine women were then pregnant and 26 had had a new delivery one year or less before follow-up. Of the women who replied, 34 (31\%) still had symptoms three years after childbirth. Five of these were pregnant again and nine had had a delivery within a year.

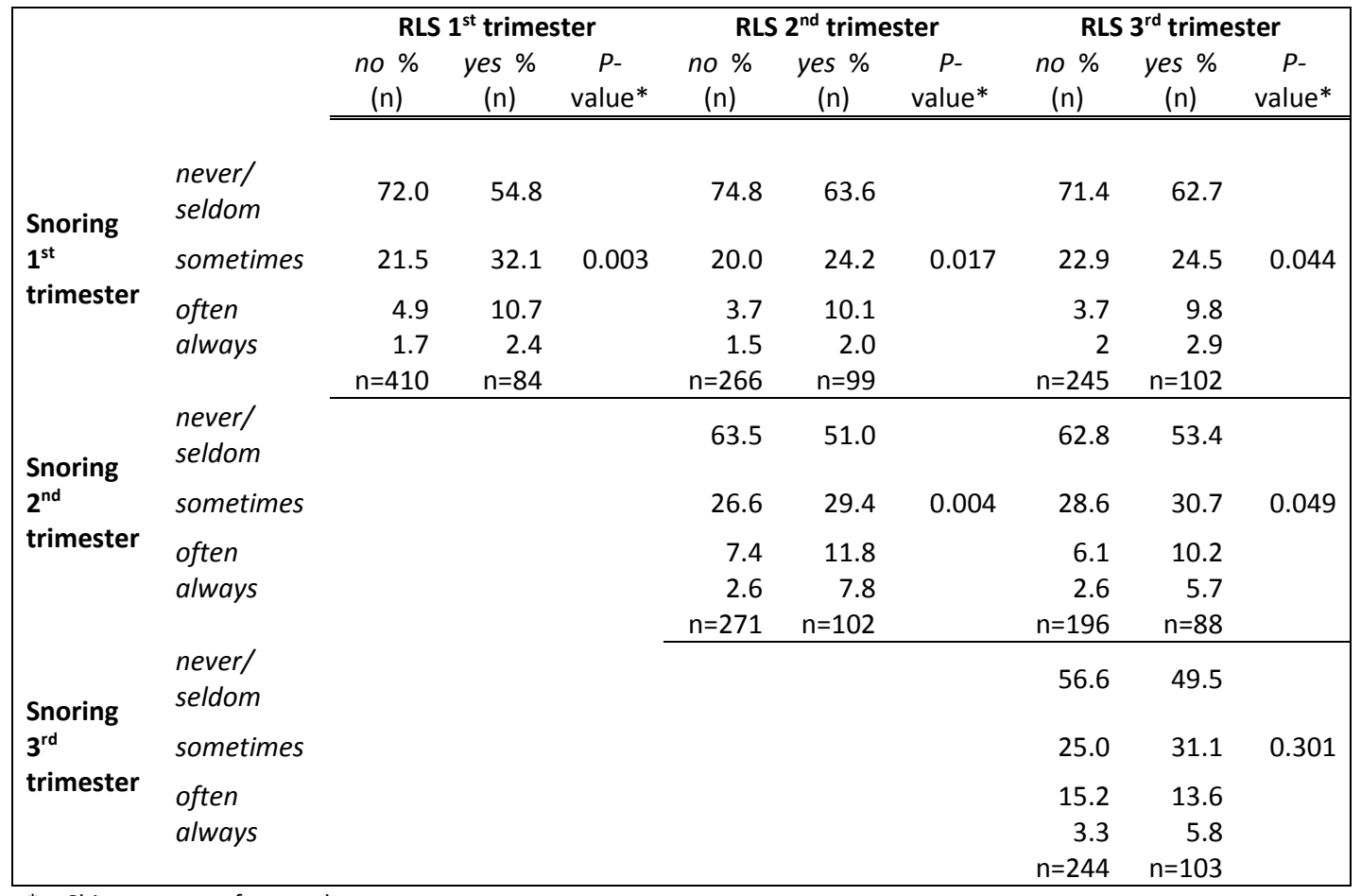

$*$ = Chi-square test for trend

Table 7. Cross-tabulation of pregnant women's experienced Restless legs syndrome (RLS) and snoring for each trimester of pregnancy. 
Of those women whose RLS-symptoms had disappeared at follow-up, 58\% stated that this happened within one month after delivery. Thus, although symptoms of RLS mostly disappear quite soon after delivery, about one-third of women with RLS during pregnancy may still have symptoms three years after childbirth.

\section{Daytime sleepiness}

The mean ESS for cohort $1(n=285$, women who had answered all three questionnaires during pregnancy) increased from 8.11 (SD 3.51) in $1^{\text {st }}$ trimester to 8.24 (SD 3.85) in $2^{\text {nd }}$ trimester and 8.91 (SD 3.86) in 3rd of pregnancy ( $\mathrm{p}<0.001$ between all groups). Excessive daytime sleepiness, defined as ESS $\geq 10$ also increased; data is shown in Figure 6c, page 42.

In cohort 1 the mean ESS differed significantly between the three groups of snorers (see Table 4, page 43). Post hoc analyses showed that the "gestational snorers" had a significantly higher mean ESS than the "non-snorers" in both the $1^{\text {st }}$ and the $3^{\text {rd }}$ trimesters of pregnancy $(p=0.009$ and $p=0.001)$, but this did not apply for the "habitual snorers" $(p=0.26$ and $p=0.39)$. The prevalence of EDS only differed between the groups in the $1^{\text {st }}$ trimester of pregnancy, with a significant difference proven between the "gestational snorers" and the "nonsnorers" $(\mathrm{p}=0.001)$. This indicates that women who started to snore at some point during pregnancy had a higher degree of sleepiness than both the women who were already snorers before pregnancy and the non-snorers, in both early and late pregnancy.

Analysis of the 285 women who answered all three questionnaires during pregnancy $(n=285)$ showed that there was an association between habitual snoring in the $2^{\text {nd }}$ and $3^{\text {rd }}$ trimesters of pregnancy and ESS-scores and EDS (ESS $\geq 10$ ) (Table 8). In these analyses RLS was only significantly associated with EDS in the $1^{\text {st }}$ trimester, but not in later trimesters, or with total ESS-score. These results differ from the results published in paper II, where analyses of all 500 women showed that women with RLS scored higher on ESS in the $3^{\text {rd }}$ trimester $(\mathrm{p}=0.008)$, but not in the $1^{\text {st }}$ or $2^{\text {nd }}$ trimester. The divergence indicates that the relationship between ESS and RLS remains unclear. High ESS was associated with postpartum depressive symptoms, displayed in Table 9. 


\begin{tabular}{|c|c|c|c|c|c|c|c|}
\hline & & $\begin{array}{c}\text { Snorers } \\
(n=54)\end{array}$ & $\begin{array}{c}\text { Non-snorers } \\
(n=231)\end{array}$ & & $\begin{array}{c}\text { RLS } \\
(n=103)\end{array}$ & $\begin{array}{c}\text { No RLS } \\
(n=182)\end{array}$ & \\
\hline & trim. & $\begin{array}{c}\text { mean (SD)/ } \\
\mathrm{n}(\%)\end{array}$ & $\begin{array}{c}\text { mean (SD)/ } \\
\mathrm{n}(\%)\end{array}$ & $p$-value & $\begin{array}{c}\text { mean (SD)/ } \\
\mathrm{n}(\%)\end{array}$ & $\begin{array}{c}\text { mean (SD)/ } \\
\mathrm{n}(\%)\end{array}$ & $\mathrm{p}$-value \\
\hline \multirow[t]{3}{*}{ ESS } & $1^{\text {st }}$ & $9.6(3.0)$ & $7.8(3.5)$ & 0.001* & $8.5(3.5)$ & $7.9(3.5)$ & 0.127 \\
\hline & $2^{\text {nd }}$ & 10.1 (3.9) & $7.8(3.7)$ & $<0.001^{*}$ & $8.7(3.7)$ & $8.0(3.9)$ & 0.138 \\
\hline & $3^{\text {rd }}$ & $11.1(3.5)$ & $8.5(3.8)$ & $<0.001^{*}$ & $09.4(3.8)$ & 8.7 (3.9) & 0.126 \\
\hline \multirow{3}{*}{$\begin{array}{l}\text { EDS } \\
(E S S \geq 10)\end{array}$} & $1^{\text {st }}$ & $24(44 \%)$ & 72 (31\%) & 0.063 & $44(43 \%)$ & $52(29 \%)$ & $0.015^{*}$ \\
\hline & $2^{\text {nd }}$ & 29 (54\%) & $81(35 \%)$ & $0.011 *$ & 42 (41\%) & $68(37 \%)$ & 0.570 \\
\hline & $3^{\text {rd }}$ & 39 (72\%) & $102(44 \%)$ & $<0.001^{*}$ & $52(50 \%)$ & 89 (49\%) & 0.797 \\
\hline \multirow{3}{*}{$\begin{array}{l}\text { Daytime } \\
\text { sleepiness }\end{array}$} & $1^{\text {st }}$ & $19(35 \%)$ & $52(23 \%)$ & 0.053 & 40 (39\%) & $31(17 \%)$ & 0.128 \\
\hline & $2^{\text {nd }}$ & $19(35 \%)$ & $46(20 \%)$ & $0.016^{*}$ & 36 (35\%) & $29(16 \%)$ & $<0.001^{*}$ \\
\hline & $3^{\text {rd } t}$ & $26(52 \%)$ & 63 (29\%) & $0.003^{*}$ & 47 (49\%) & $42(24 \%)$ & $<0.001 *$ \\
\hline \multirow{3}{*}{$\begin{array}{l}\text { Morning } \\
\text { fatigue }\end{array}$} & $1^{\text {st }}$ & $26(48 \%)$ & $54(23 \%)$ & $<0.001^{*}$ & $37(36 \%)$ & $43(24 \%)$ & $0.026^{*}$ \\
\hline & $2^{\text {nd }}$ & $25(46 \%)$ & $47(20 \%)$ & $<0.001^{*}$ & $27(26 \%)$ & 45 (25\%) & 0.781 \\
\hline & $3^{\text {rdt+ }}$ & $2343 \%)$ & $55(24 \%)$ & $0.006 *$ & $38(38 \%)$ & $40(22 \%)$ & $0.005^{*}$ \\
\hline
\end{tabular}

${ }^{\dagger} n=282 ;{ }^{+\dagger} n=271$

Table 8. Different measures of sleepiness and tiredness and its association to snoring (subjective habitual snoring in $2^{\text {nd }}$ or $3^{\text {rd }}$ trimester) and RLS (diagnosed anytime during pregnancy). $n=285$, women who have answered all three questionnaires during pregnancy.

In the questionnaires the women also rated their degree of morning fatigue and daytime sleepiness by answering two separate questions. The results for women who had answered all three questionnaires $(n=285)$ are shown in Table 8. Both women who snored in the $2^{\text {nd }}$ and $3^{\text {rd }}$ trimesters and women with RLS scored higher on these questions at most occasions. Statistical correlation between the answers to the questions about morning fatigue/daytime sleepiness and ESS-score was weak and rho never exceeded 0.4. This indicates that ESS and the separate questions about fatigue and sleepiness might measure different aspects of sleepiness.

In cohort 2 the median total ESS for the pregnant women and controls were 9 and 7 respectively ( $\mathrm{p}<0.001) .37$ pregnant women $(42 \%)$ and 14 controls $(17.5 \%)$ had EDS $(\mathrm{p}=0.001)$. Neither among pregnant nor among non-pregnant women was any statistically significant association found between EDS and subjective ( $\mathrm{p}=0.860$ and 0.462 , respectively) or objective snoring ( $\mathrm{p}=0.781$ and 0.760 , respectively). Therefore, development of OSA is not a likely explanation for the daytime sleepiness common during pregnancy.

Regarding the separate items in the ESS the only significant result was for item 4 where non-pregnant women scored higher than pregnant women. However, after 
adjusting the p-value for multiple testing this difference vanished (for more details see paper IV).

\section{Postpartum depressive symptoms}

The 293 women from cohort 1 who had answered both the questionnaire in the $3^{\text {rd }}$ trimester and completed the EPDS at the postpartum check-up had a mean EPDS score of 4.96 (range 0-22, SD 3.42). Twenty-nine women (9.9\%) had an EPDS score $\geq 10$. Known risk factors for PPD were confirmed in our study: previous PPD, low education level, preterm delivery and depression during the current pregnancy. We also found associations between high prevalence of depressive symptoms in the postpartum period and sleep-related problems as shown in Table 9. This shows that depressive symptoms after childbirth are already preceded by disturbed sleep during pregnancy. The results from the ESS completed during pregnancy might be used for detecting women at risk, enabling preventive interventions.

\begin{tabular}{|c|c|c|c|c|c|c|c|}
\hline & \multicolumn{2}{|c|}{$\begin{array}{c}\text { EPDS }<10 \\
n=264\end{array}$} & \multicolumn{2}{|c|}{$\begin{array}{c}\text { EPDS } \geq 10 \\
n=29\end{array}$} & \multirow[b]{2}{*}{ p-value } & \multirow[b]{2}{*}{ OR $(95 \% \mathrm{Cl})$} & \multirow[b]{2}{*}{ Adj. $\mathrm{OR}^{++}(95 \% \mathrm{Cl})$} \\
\hline & $\mathbf{n}$ & $\%$ & $\mathbf{n}$ & $\%$ & & & \\
\hline \multicolumn{8}{|l|}{$\begin{array}{l}\text { Excessive daytime } \\
\text { sleepiness }(\mathrm{ESS} \geq 10)\end{array}$} \\
\hline $\mathrm{Ye}$ & 91 & 34.5 & 17 & 58.6 & 0.010 & $2.69(1.23-5.88)$ & 3.84 (1.57-9.39) \\
\hline $\mathrm{Nc}$ & 173 & 65.5 & 12 & 41.4 & & Reference & \\
\hline \multicolumn{8}{|l|}{ Daytime sleepiness } \\
\hline $\mathrm{Ye}$ & 75 & 30.1 & 15 & 57.7 & 0.004 & $3.16(1.39-7.21)$ & $3.29(1.30-8.33)$ \\
\hline Nc & 174 & 69.9 & 11 & 42.3 & & Reference & \\
\hline \multicolumn{8}{|l|}{ Morning fatigue $^{+}$} \\
\hline $\mathrm{Ye}$ & 58 & 22.1 & 14 & 50.0 & 0.001 & $3.52(1.59-7.80)$ & $3.17(1.27-7.87)$ \\
\hline $\mathrm{Nc}$ & 204 & 77.9 & 14 & 50.0 & & Reference & \\
\hline \multicolumn{8}{|l|}{ Habitual snoring } \\
\hline $\mathrm{Ye}$ & 52 & 20,0 & 6 & 23.1 & 0.710 & $1.20(0.46-3.14)$ & $0.98(0.31-3.11)$ \\
\hline $\mathrm{Nc}$ & 208 & 80,0 & 20 & 76.9 & & Reference & \\
\hline \multicolumn{8}{|l|}{ Restless legs syndrome } \\
\hline $\mathrm{Ye}$ & 75 & 28.4 & 14 & 48.3 & 0.027 & $2.35(1.08-5.11)$ & $2.84(1.18-6.84)$ \\
\hline No & 189 & 71.6 & 15 & 51.7 & & Reference & \\
\hline
\end{tabular}

+3 women did not answer this question

t† adjusted for baseline data (age, relationship status, parity, BMI, smoking, prior psychiatric disease) and statistically significant risk factors for PPD (education level, previous PPD, depression during current pregnancy, premature birth)

Table 9. Associations between high prevalence of depressive symptoms in the postpartum period and sleep related problems during pregnancy. 


\section{Obstetric outcomes}

Except for postpartum depressive symptoms, we found no convincing impact of the sleep disorders we investigated on obstetric outcomes in our study. We evaluated associations between sleep disorders and preeclampsia and gestational hypertension, gestational diabetes, mode of delivery, fetal growth, premature birth and major complications during pregnancy and labor.

Of all the participating women who were delivered in cohort $1(n=480), 17(3.5 \%)$ developed preeclampsia (two of these also developed eclampsia) and one developed gestational hypertension. Five women developed gestational diabetes. Due to different inclusion criteria for the subjects in the separate papers, not all of the women with complications were analyzed in all papers. However, even when considering all 480 women, no statistical significance was found between snoring or RLS and preeclampsia (incl. gestational hypertension). Neither was snoring nor RLS associated with elevated blood pressure (without clinical hypertension) during pregnancy.

When many obstetric complications are grouped together, there are statistically significant associations between habitual snoring in the $2^{\text {nd }}$ and $3^{\text {rd }}$ trimesters of pregnancy and complications during both pregnancy and delivery (Table 10). These findings have not been published. Although grouped outcomes are difficult to interpret, these observations might indicate an increased vulnerability for snoring women.

The snoring and non-snoring women had similar mean BMI (25.1 and 24.1 respectively, $\mathrm{p}=0.063$ ), but when categorizing the BMI a greater share of the snoring women were overweight and obese $(\mathrm{p}=0.01)$. This indicates that obesity might contribute to the complication rate. 


\begin{tabular}{|lcccc|}
\hline & \multicolumn{4}{c|}{ Habitual snorers $^{\dagger}$} \\
& $\begin{array}{c}\text { Total } \\
\text { Yes }(\mathbf{n}=65)\end{array}$ & $\begin{array}{c}\text { No }(\mathbf{n}=\mathbf{4 1 5}) \\
\mathrm{n}(\%)\end{array}$ & p-value \\
\cline { 2 - 5 } & $\mathrm{n}$ & $\mathrm{n}(\%)$ & $\mathrm{n}(\%)$ & \\
Gestational diabetes & 18 & $3(5 \%)$ & $15(4 \%)$ & 0.693 \\
Other complication during pregnancy $^{2}$ & 5 & 0 & $5(1 \%)$ & 0.374 \\
Complication during or after delivery $^{3}$ & 21 & $9(14 \%)$ & $12(3 \%)$ & $<0.001^{*}$ \\
Instrumental delivery or cesarean section & 56 & $14(22 \%)$ & $41(10 \%)$ & $0.002^{*}$ \\
\hline
\end{tabular}

${ }^{1}$ Including 1 women with gestational hypertension

${ }^{2}$ Severe hyperemesis, contractions leading to sick leave $>2$ weeks, back or pelvic girdle pain needing for medical counselling, abnormal vaginal bleeding needing hospitalization, carpal tunnel syndrome, cholestasis of pregnancy or thromboembolic disease

${ }^{3}$ Bleeding $>1000 \mathrm{ml}$, rupture of the anal sphincter, urine retention, pneumonia or postpartum endometritis ${ }^{+}$Subjective habitual snoring in $2^{\text {nd }}$ and/or $3^{\text {rd }}$ trimester of pregnancy

Table 10. Obstetric complications in cohort $1(n=480$, all delivered women). 


\section{General discussion}

\section{Discussion of the methodology}

In this study, the women in cohort 1 were consecutively recruited at their first visit to the ACC in order to avoid selection bias. A limitation is that it is not known how many women were asked to participate and how many did refrain from participating. The prospective design was chosen to avoid recall bias and to enable distribution of repeated questionnaires to the same women, making it possible to evaluate the development of sleep-related disorders during pregnancy. A disadvantage of this design is that it is hard to get every woman to complete all questionnaires and to take into consideration the complex nature of the data collected, since some women who failed to complete the $2^{\text {nd }}$ questionnaire did complete the $3^{\text {rd }}$, see Figure 3, page 28. Some women also did not answer every one of the questions. We have tried to make a survey of the causes of drop-out after inclusion, but many drop-outs were not able to provide reasons. A probable explanation is that the midwives sometimes forgot to distribute the questionnaire. In order to interpret all results it was necessary to construct strict inclusion criteria for the different analyses. The different inclusion criteria used in the separate papers results in not all women with complications being included in all analyses. This can of course have an effect on some of the results.

All medical data were drawn from the standardized antenatal and delivery records. The Swedish national antenatal care system requests that information about the pregnant women's weight, blood pressure, medications etc. be collected at the routine visits, and therefore the information is largely complete. The few missing figures were mostly those regarding weight, and it is important to take into consideration the possibility that the women for whom weight is missing were either underweight or overweight and therefore did not want to reveal their weight. Information about the delivery includes diagnoses concerning delivery complications indicating traumatic delivery. However, the women's own experiences of the delivery and pregnancy might differ substantially from the objective information in a medical record, and we have not asked the women themselves if they consider their pregnancy or delivery to have been traumatic or complicated. 
Questionnaires were used for evaluating sleep. The questionnaire was short and took less than five minutes to fill in, making participation in the study more attractive for both women and their midwives, enabling a larger study population. A problem when using questionnaires is to know what you are actually measuring. The questions have to be easy to understand and the answers have to be reliable. Validated questionnaires are preferable.

We used the ESS for investigating sleepiness. It is a widely used screening instrument for detecting daytime sleepiness, developed by M.W. Johns in 1991 (113) and it has been validated for use not only for OSA but also for sleepiness due to other reasons $(125,126)$ and it has also been validated for use in a pregnant population (114). The Swedish version was translated by Jan-Erik Broman upon request by the Swedish Society for Sleep Research and Sleep Medicine. It has been back-translated into English and approved by M.W. Johns, but there is no published validation of the Swedish version. Much criticism has been directed against the ESS. For example, some of the separate items are not clearly formulated, and there is an unidimensionality of the scale; (items that most people could score high and items that represent situations where there is a very low probability of falling asleep should be referred to as different dimensions and not analyzed together as a sum). There is also an uncertainty concerning what is actually measured and there is limited evidence on the test-retest reliability and for use for individual level comparison $(127,128)$. However, there is no available alternative that provides an easy to use, brief, and inexpensive approach to assessment of chronic sleepiness. The ESS also does standardize collection of similar information between different clinicians or sites making it possible to compare results from different studies using the ESS.

The separate questions in our questionnaire about snoring, apneas, fatigue, and sleepiness, where the women are asked to rate their answers from never to always, are frequently used in clinical sleep medicine, but they have not been validated. The women were asked to fill in the questionnaire themselves, and their partners were not asked for their opinions, which had they been asked might have increased the reliability. A possible improvement would also be to retrospectively ask the women about their rate of snoring, RLS and daytime sleepiness before becoming pregnant. This information could increase understanding of the impact of pregnancy on sleep disorders. 
In order to detect RLS, the set of four questions recommended for populationbased epidemiologic studies by the International RLS Study Group was used (46). Since the women only filled in their answers in the questionnaire and no personal contact was made, there was no actual possibility to be sure of the diagnosis RLS.

The EPDS instrument has been validated multiple times for screening for PPD, both in its original English version and in the Swedish translation (116-118). When choosing the cut-off level $\geq 10$, the sensitivity for detection of major depression is almost $100 \%$ and the specificity $82 \%$ (129). The EPDS is widely used in clinical care all over the world in order to screen for postnatal depression. It has also been a part of the routine check-up after delivery at the ACC in Linköping for many years. EPDS has also been validated for detecting depression during pregnancy (130) and it is now also part of the routine at the first visit at some ACC:s in order to detect depressive symptoms during pregnancy. This practice was, however, only implemented after this study was finished.

When investigating the connection between sleep and depressive symptoms, we intentionally chose to evaluate possible sleep disturbances by use of the ESS, despite the fact that this does not actually say anything about nocturnal sleep. Using an established screening instrument makes application of the results easier, since the same tool can be used in the clinic as part of the normal antepartum program. Although there might be an advantage to objectively evaluating sleep, published data claim that the association between postpartum mood and the subjective perception of sleep actually is stronger than the association between postpartum mood and objective sleep quality and duration $(101,102)$. However, since poor sleep and fatigue might be symptoms of an already existing depression, it is possible that a high ESS score during pregnancy could actually indicate an antepartum depression. This theory has also been presented in studies about sleep and antepartum depression (94). It is a limitation that the women did not complete the ESS as well as the EPDS at both the $3^{\text {rd }}$ trimester visit and at the postpartum check-up. Use of such a study design would probably have revealed if daytime sleepiness precedes depressive symptoms or vice versa.

The lack of significance concerning a correlation between snoring and preeclampsia and hypertension might indicate that our study was underpowered with too small sample size. The prevalence of preeclampsia in our material corresponds well with the prevalence among Swedish pregnant women (109), 
which suggests that the material is representative. The sample size of 500 women in our study was chosen empirically, since the retrospective study we aimed to verify (111) included 502 women and showed a correlation between snoring and preeclampsia. Similar results are reported from other retrospective studies with the same (131) or smaller (42) sample sizes. However, a post hoc power analysis indicates that a double sample size might be demanded for statistical power of $80 \%$.

In this study the Embletta device was used, which has the disadvantage that snoring is identified through vibrations in the nasal cannula and not through recording of sound which might underestimate the frequency of snoring. It has also been shown that there exists a gender difference in vocal tract dimensions, elastic properties of tissues and prephonatory glottal shapes that are involved in human speech production (132-134). It is therefore highly likely that acoustic and vibratory properties of snores may be affected by gender differences. This might explain the difference in objective vs. subjective snoring in the present study. General limitations of home sleep studies are that there is no objective measurement of sleep time and there is an increased risk of data loss due to sensor failure $(135,136)$.

In cohort 1, a majority of the snoring women abstained from participating in the nocturnal respiratory recording offered to them. We speculated about the reasons for this. Many women were offered this sleep recording after gestational week 35 , as they were approaching the time for delivery. Actually, for one woman labor started the same night on which she was scheduled to conduct her recording. Since the women accepted participation in early pregnancy they might not fully have considered the respiratory recording at inclusion. It is also possible that women offered nocturnal recording already suffered from disturbed sleep and sleepiness, so they did not want to affect the sleep further.

Since the respiratory recordings from cohort 1 were too few to make a reliable interpretation, we decided to approach the women in cohort 2 at the actual time for the planned recording, making it more explicit that participation in the study implied that they would actually be expected to undergo nocturnal respiratory investigations. The disadvantage of this is that women who suffer from disturbed sleep to greater extent might choose to decline participation. 
In cohort 2 sleep recordings were performed on a large number of unselected pregnant women without specific risk factors and compared to those of nonpregnant, age-and BMI-matched controls. Other theoretical risk factors, such as smoking, alcohol consumption, parity, preferred supine sleeping position or wide neck circumference were not matched for. The same physician scored all sleep recordings. If the same women had been investigated during and after pregnancy, it might have been possible to clarify whether the pregnancy actually influenced the breathing for the separate individuals.

The major strength of this survey was its prospective design and reliability. Women were consecutively recruited in early pregnancy and followed during and after pregnancy and a fairly large number of nocturnal respiratory recordings were conducted on pregnant and non-pregnant women. Validated instruments for measuring depressive symptoms (EPDS), sleepiness (ESS) and RLS were used. The main limitations were insufficient power to verify all investigated outcomes, absence of pre-pregnancy data and lack of information about depressive symptoms during pregnancy and about sleep (except RLS) after delivery. 


\section{Discussion of the results}

\section{Snoring}

Our data suggest that snoring is more common in pregnant than in non-pregnant women and that the prevalence of snoring increases during pregnancy. This is in line with findings from most other studies, the most often cited reported snoring in $14 \%$ of pregnant women and $4 \%$ of non-pregnant controls (39). Our finding that edema in hands, legs and feet in the $3^{\text {rd }}$ trimester of pregnancy is associated with snoring has not been reported earlier, but it supports the theory that snoring during pregnancy is caused by smaller upper airway dimensions in pregnant women (1).

We found a low prevalence of objectively recorded OSA, identified as AHI $\geq 5$, in both pregnant (1\%) and non-pregnant (3\%) women. Similar results are described in a large American study from the year 2000 where none of the investigated pregnant women had an $A H I \geq 5$ (41). Most other surveys using sleep recording on pregnant women have focused on smaller groups with known risk factors such as chronic snoring, hypertension, preeclampsia or obesity, and have found a higher prevalence of OSA both in investigated groups and controls (137-143). We have speculated that another reason for the discrepancy in prevalence of SDB might be due to differences in the practice of manual recording scoring vs. automatic scoring, i.e., when scoring is done by the manufacturers software. A third reason for discrepancies is that hypopneas has been counted in some studies when hypopneas resulted in $3 \%$ desaturations, whereas in others, including ours, when hypopneas resulted in $4 \%$ desaturations. We found more pathological values in the sleep recordings in cohort $1(n=33)$ than in the recordings in cohort 2. A possible reason for this is that only habitually snoring women were offered sleep recording in cohort 1 .

\section{Restless Legs Syndrome}

The prevalence of RLS is known to increase during pregnancy, and our results resemble those from other published studies (66). Previous studies have stated that the highest prevalence is in the $3^{\text {rd }}$ trimester of pregnancy (144-146), but we found a significant increase already between the $1^{\text {st }}$ and $2^{\text {nd }}$ trimester of pregnancy. Later studies have confirmed earlier onset of RLS (147).

We found an association between snoring and RLS, and this has also been previously described in the general population (148). The association between 
RLS and snoring during pregnancy is also supported by a recently published study (149). Since part of the explanation for the increasing prevalence of RLS during pregnancy is the established levels of estrogen (3), and the high levels of estrogen also impact the airways, leading to narrowing and increased risk of snoring $(1,2)$; thus the connection between RLS and snoring during pregnancy probably is due to hormonal factors. The inflammatory response described in both snoring/OSA and RLS $(4,5)$ is also a possible explanation for this association.

At one time, RLS was thought to always disappear soon after delivery $(68,146$, $150,151)$, but newer studies support our findings that for some women RLS persists several years after child birth and may develop into chronic disease (50, 152, 153). This makes it probable that whether the symptoms of RLS disappear or not during the first month after childbirth depend on whether the affected woman has suffered from transient RLS during her pregnancy or if her pregnancy has triggered the onset on persistent RLS.

\section{Daytime sleepiness}

An increasing prevalence of daytime sleepiness during the progress of pregnancy was found in cohort 1, and higher ESS scores and higher prevalence of EDS (identified as ESS $\geq 10$ ) were found in cohort 2 compared to the non-pregnant controls. It is well known that most women are more tired and sleepy when they are pregnant. This has been shown using different screening tools $(146,154,155)$.

Increased daytime sleepiness during pregnancy has often been explained by increased SDB or snoring $(156,157)$. Our findings concerning daytime sleepiness and its association with snoring are somewhat divergent. In cohort 1 there was an association between snoring in the $2^{\text {nd }}$ and $3^{\text {rd }}$ trimesters of pregnancy and increased ESS-scores and EDS. By separating women who started to snore during pregnancy from women who snored already in early pregnancy, it can be seen that the former had a higher degree of sleepiness than non-snorers in both early and late pregnancy (paper I). In cohort 2 no association was found between EDS $(E S S \geq 10)$ and subjective or objective snoring, either among pregnant or among non-pregnant women. Thus, although daytime sleepiness during pregnancy probably not is caused by OSA, subjective snoring might be part of the explanation for the increased daytime sleepiness seen in pregnancy. 


\section{Postpartum depressive symptoms}

We found an association between high prevalence of depressive symptoms in the postpartum period and high ESS score, daytime sleepiness, morning fatigue and restless legs symptoms in the last trimester of pregnancy. Since disturbed sleep might precede depressive symptoms in the general population (85) and poor sleep quality in early pregnancy might contribute to antepartum depressive symptoms during pregnancy (92) it is likely that poor sleep during pregnancy increases vulnerability for development of PPD. Although review articles state that there is an association between sleep and pre-and postpartum depressive symptoms (158, 159), studies focusing on the connection between sleep during pregnancy and depressive symptoms after delivery are either rather small (96-98) or have only considered insomnia $(99,100)$. The results from these surveys are also contradictory. Thus, our findings might contribute to increased knowledge about the mechanism for development of PPD. Our results do not, however, clarify which occurs first, sleep disturbance or depressive symptoms. The association between prevalence of RLS in last trimester of pregnancy and depressive symptoms in the postpartum period is supported by the reported correlation between RLS and major depression in the general population (160-162). A newly published paper has reported that women with RLS onset before pregnancy had an increased risk of both antenatal and postnatal depression (71).

The prevalence of EPDS $\geq 10$ was $9.9 \%$ among the women in our study, which is somewhat lower than reported by other research (163). This might reflect the fact that the ACC where our women were recruited was one of the first in Sweden that used the EPDS as a screening tool and the awareness of depressive symptoms, both during pregnancy and postpartum, is thus high among midwives and physicians at that ACC.

\section{Obstetric outcomes}

In our studies, we found no convincing associations between sleep disorders and investigated obstetric outcomes other than postpartum depressive symptoms. There is a growing literature on the impact of maternal OSA on hypertensive disorders of pregnancy, gestational diabetes and impaired fetal growth $(103,164)$. Therefore we have focused on these outcomes in our study, but have not been able to verify these possible connections. 
However, when several complications of pregnancy or delivery are grouped together, we found an association between habitual snoring and adverse outcomes. The snoring women had higher BMI when divided into BMI-classes. This indicates that snoring women might have increased vulnerability during pregnancy and labor, maybe also impacted by the higher prevalence of obesity in these women. Increased inflammatory response is reported in snoring/OSA, restless legs and sleep deprivation cases $(4,5,165)$ as well as in preeclampsia, gestational diabetes and maternal stress cases $(110,159,166)$. Obesity, a known risk-factor for many of these conditions, is also associated with inflammation (167) and adverse obstetric outcome (168). A possible theory would hence be that inflammation, caused by sleep disorders (and obesity) could affect the development of adverse obstetric outcomes.

\section{Future research}

In our study, snoring women had a higher, but not statistically significant prevalence of preeclampsia. Since we were not able to verify or reject the association shown by Franklin et al, it would be interesting to conduct the same study once again, with a double sample size. Then pre-pregnancy sleep related data should also be asked for. The best setting would be to conduct sleep respiratory recording on all participating women, both during pregnancy and after delivery (preferably not in the postpartum period, but about one year after delivery when both mother and child have a more stabilized sleep pattern). Regarding postpartum depressive symptoms, the EPDS should be filled in also during pregnancy.

Since we found evidence that women who snore are more prone to be affected by unspecific complications during pregnancy and delivery it would also be interesting to further investigate this relationship. To demonstrate if such an association exists, an epidemiological study would preferably be performed. A large cohort of women could then be approached with a questionnaires about their sleep (especially snoring) during pregnancy and the answers compared to data drawn from the Swedish birth register (169). If an epidemiological association was found, the relation could be further analyzed by comparing the levels of sex hormones and inflammatory markers in the serum of snoring and non-snoring pregnant women. 
However, the current study together with many other surveys regarding sleep and pregnancy has showed that sleep during pregnancy is important. Future research should therefore focus on how best to help women to attain better sleep during their pregnancies. 


\section{Conclusions}

- The frequency of snoring does increase during pregnancy and is associated with higher BMI at the start of pregnancy and higher frequency of edema in late pregnancy. Women who started to snore at some point during pregnancy, but not the women who snored from the very beginning of pregnancy, had a higher degree of sleepiness than the non-snorers in both early and late pregnancy. No significant association between snoring, hypertension and obstetric outcome was found.

- Restless legs syndrome (RLS) increases during pregnancy, with significant increase already between the $1^{\text {st }}$ and $2^{\text {nd }}$ trimesters of pregnancy. Symptoms of RLS disappear quite soon after delivery. However, about one-third of women with RLS during pregnancy still have symptoms three years after childbirth, which indicates that RLS during pregnancy is a risk factor for chronic RLS. Women who snored in the $1^{\text {st }}$ or $2^{\text {nd }}$ trimester of pregnancy had a higher prevalence of RLS in the $3^{\text {rd }}$ trimester which might indicate that snoring in early pregnancy predicts RLS.

- Daytime sleepiness, probably caused by disturbed sleep during pregnancy, increases the risk of postpartum depressive symptoms. This is true particularly when considering excessive daytime sleepiness during pregnancy, identified as Epworth Sleepiness Score (ESS) $\geq 10$. This association suggests that ESS scoring during pregnancy might be used for detecting women at risk for postpartum depression, enabling optimal preventive interventions. The presence of RLS during late pregnancy is also associated with postpartum depressive symptoms.

- Snoring, both objectively and subjectively measured, was more common in the pregnant women than in non-pregnant controls. However, nocturnal respiratory recordings could not verify an increased prevalence of sleep disordered breathing or obstructive sleep apnea (OSA). Pregnant women had higher ESS-scores than the non-pregnant women, but this was not related to snoring in this cohort. Therefore, development of OSA is not a likely explanation for the daytime sleepiness common during pregnancy. 


\section{Populärvetenskaplig sammanfattning på svenska}

De flesta kvinnor upplever att de sover sämre när de är gravida och studier har visat att sömnen påverkas på flera olika sätt av en graviditet. Bland annat ökar förekomsten av snarkning. Snarkning i sig kan störa sömnen, men snarkning kan också vara ett symptom på obstruktivt sömnapnésyndrom. Detta är en sjukdom som innebär att luftflödet blockeras i svalget när man sover, vilket leder till andningsuppehåll och störd sömn. Andningsuppehållen orsakar ett stresspåslag i kroppen, med en aktivering av det sympatiska och parasympatiska nervsystemet. Detta i sin tur kan leda till förhöjt blodtryck. Det finns ett konstaterat samband mellan obstruktivt sömnapnésyndrom och kronisk hypertoni (högt blodtryck) hos en icke-gravid normalbefolkning. Studier antyder att detta samband kan finnas även hos gravida. Högt blodtryck hos en gravid kvinna kan vara ett tecken på havandeskapsförgiftning (preeklampsi), vilket kan utvecklas till ett potentiellt livshotande tillstånd för mor och barn. De flesta studier på detta område inriktar sig dock på redan förlösta kvinnor och det har varit svårt att klargöra om snarkningen eller havandeskapsförgiftningen utvecklats först.

Även tillståndet restless legs (RLS), ibland även kallat Ekbom-Willis sjukdom, ökar under graviditet. Denna sjukdom karaktäriseras av ett tvång att röra benen och en känsla av obehag (som myrkrypningar eller stickningar) i ben och/eller armar. Symptomen lindras av rörelse och förvärras av inaktivitet eller vila och besvären är starkare på kvällen och natten vilket gör det svårt att sova. RLS är vanligare förkommande hos kvinnor än män. Exakt hur det utvecklas under graviditet och vad som händer med symptomen efter förlossningen är inte kartlagt hos svenska gravida kvinnor.

Tiden efter förlossningen innebär en stor omställning för de flesta kvinnor. Drygt 1 av 10 kvinnor utvecklar en förlossningsdepression under denna period, vilket har stora negativa konsekvenser både för mor och barn. Det är välkänt att sömn och depression är nära sammankopplat och nyare forskning har visat att en depression kan föregås av störd sömn. Forskning om förlossningsdepression och sömn fokuserar ofta på sömnen efter förlossningen, men det finns också påvisade samband mellan störd sömn under graviditeten och depressionsutveckling innan 
barnet är fött. Man vet däremot inte om störd sömn redan innan förlossningen kan innebära en ökad risk för depression efter att barnet är fött.

I studierna som ingår i denna avhandling har vi undersökt hur snarkning och sömnapnésyndrom utvecklas under graviditet och om det finns kopplingar mellan snarkning och havandeskapsförgiftning. Vi har också kartlagt hur förekomsten av RLS och trötthet utvecklas under graviditet. Dessutom har vi undersökt om störd sömn under graviditeten påverkar risken för att utveckla depression efter förlossningen.

Vi har undersökt 500 gravida kvinnor som fått fylla i en enkät vid tre tillfällen under graviditeten och sedan följts upp efter förlossningen. Vi har använt oss av vedertagna screening-instrument avseende dagtrötthet (Epworth Sleepiness Scale) och depressionssymptom (Edinburgh Postnatal Depression Scale). För att närmare kunna undersöka sömnapnésyndrom hos gravida har vi också låtit 100 gravida kvinnor genomgå en natts sömnregistrering och jämfört med sömnregistreringar gjorda på 80 icke-gravida kvinnor.

Resultaten visade att både snarkning och RLS ökar under graviditet. Kvinnor som snarkar tidigt i graviditeten löper ökad risk att utveckla RLS. De flesta kvinnor som lider av RLS blir av med besvären inom en månad efter förlossningen, men 1 av 3 har kvar sina besvär tre år efter förlossningen. Även dagtrötthet ökar under graviditet och är till viss del kopplat till förekomsten av snarkning. Sömnregistreringarna kunde dock inte visa att gravida lider av obstruktivt sömnapnésyndrom i högre utsträckning än icke-gravida kvinnor och därför är det osannolikt att obstruktivt sömnapnésyndrom orsakar graviditetströtthet. Det fanns inga säkra samband mellan snarkning och havandeskapsförgiftning. Däremot visade det sig att kvinnor som upplevde störd sömn och ökad dagtrötthet under graviditeten hade ökad risk för att utveckla depression efter förlossningen.

Eftersom sömnen påverkas negativt av graviditet och detta kan påverka risken att drabbas av depression efter förlossningen är det viktigt att sjukvårdpersonal aktivt frågar hur gravida kvinnor sover och har kunskap om hur man kan bidra till en förbättrad sömn. 


\section{Acknowledgements}

This thesis would never have existed without my supervisors Ann Josefsson and Eva Svanborg. However, there are many persons whose help and support have been of great importance for this project and whom I therefore would like to thank:

Associate Professor Ann Josefsson for always having a positive mind, even in the situations when I lost my faith in this project. I really appreciate your enthusiasm and quick and valuable feedback.

Professor Eva Svanborg for introducing me to the world of sleep medicine, inviting me to interesting meetings and inspiring me with your never-ceasing ideas of new angles in approaching the issue of sleep during pregnancy.

Associate Professor Ann-Britt Wiréhn for your patience when I took my first stumbling steps in the world of statistics. I hope that I have learned a lot since!

Marie Bladh for clever solutions and many laughs.

Dr Lena Harder for great help with handling and interpreting the massive material.

All 680 participating women who have lent me your time and sleep. It is my responsibility to you that has helped me carry on with this project at times when my inspiration was lacking.

All midwives at ACC Linköping, especially research midwives Pia Cederholm and Cecilia Rostedt for valuable help with recruiting the women.

Professor emeritus Göran Berg, Dr Ninnie Borendal Wodlin, Dr Caroline Lilliecreutz, Professor Gunilla Sydsjö and Dr Martin Ulander for reading my papers and manuscripts and contributing with valuable opinions.

Professor Lawrence Lundgren, for quick and interactive linguistic help.

All friends and colleagues at the Department of Obstetrics and Gyneaclogy at the University Hospital in Linköping, for making me enjoy every day at work. And for giving me the time and opportunity to complete my doctoral thesis. I deeply appreciate you all! 
All staff at the Department of Clinical Neurophysiology at the University hospital in Linköping for your help with all practical things regarding the respiratory recordings.

My friends. I know I have spent far too little time with you the past years, but I hope to make up for this in the future!

Robert, the love of my life and best friend. For everything.

Our wonderful children Linus, Tilde and Simon for showing me what is important in life.

My parents, Anders and Margareta, your spouses Marianne and Sture and my parents in law, Inger and Jan, for helping us out when time was scarce and the children was ill. And of course for your never ending love and support. 


\section{References}

1. Izci B, Vennelle M, Liston WA, Dundas KC, Calder AA, Douglas NJ. Sleepdisordered breathing and upper airway size in pregnancy and post-partum. Eur Respir J. 2006;27(2):321-7.

2. Elkus R, Popovich J, Jr. Respiratory physiology in pregnancy. Clin Chest Med. 1992;13(4):555-65.

3. Dzaja A, Wehrle R, Lancel M, Pollmacher T. Elevated estradiol plasma levels in women with restless legs during pregnancy. Sleep. 2009;32(2):169-74.

4. Nadeem R, Molnar J, Madbouly EM, Nida M, Aggarwal S, Sajid H, et al. Serum inflammatory markers in obstructive sleep apnea: a meta-analysis. Journal of clinical sleep medicine : JCSM : official publication of the American Academy of Sleep Medicine. 2013;9(10):1003-12.

5. Weinstock LB, Walters AS, Paueksakon P. Restless legs syndrome--theoretical roles of inflammatory and immune mechanisms. Sleep medicine reviews. 2012;16(4):341-54.

6. Evain-Brion D, Malassine A. Human placenta as an endocrine organ. Growth hormone \& IGF research : official journal of the Growth Hormone Research Society and the International IGF Research Society. 2003;13 Suppl A:S34-7.

7. Creasy RK, Resnik R, Iams JD. Maternal-fetal medicine : principles and practice. 5th ed ed. Philadelphia.: Saunders; 2004. xviii, 1362 p., 23 p. of plates p.

8. Porkka-Heiskanen T, Zitting KM, Wigren HK. Sleep, its regulation and possible mechanisms of sleep disturbances. Acta physiologica. 2013;208(4):311-28.

9. C I, S A-I, Jr. CA, SF Q. The AASM manual for the scoring of sleep and associated events: rules, terminology and technical specifications. 1st ed2007.

10. Lee-Chiong TL. Sleep medicine : essentials and review. Oxford ; New York: Oxford University Press; 2008. 703 p. p.

11. Schweiger MS. Sleep disturbance in pregnancy. A subjective survey. Am J Obstet Gynecol. 1972;114(7):879-82.

12. Suzuki S, Dennerstein L, Greenwood KM, Armstrong SM, Satohisa E. Sleeping patterns during pregnancy in Japanese women. Journal of psychosomatic obstetrics and gynaecology. 1994;15(1):19-26.

13. Lee KA, Zaffke ME, McEnany G. Parity and sleep patterns during and after pregnancy. Obstetrics and gynecology. 2000;95(1):14-8.

14. Hertz G, Fast A, Feinsilver SH, Albertario CL, Schulman H, Fein AM. Sleep in normal late pregnancy. Sleep. 1992;15(3):246-51.

15. Wilson DL, Barnes M, Ellett L, Permezel M, Jackson M, Crowe SF. Decreased sleep efficiency, increased wake after sleep onset and increased cortical arousals in late pregnancy. The Australian \& New Zealand journal of obstetrics \& gynaecology. 2011;51(1):38-46.

16. Brunner DP, Munch M, Biedermann K, Huch R, Huch A, Borbely AA. Changes in sleep and sleep electroencephalogram during pregnancy. Sleep. 1994;17(7):576-82.

17. Driver HS, Shapiro CM. A longitudinal study of sleep stages in young women during pregnancy and postpartum. Sleep. 1992;15(5):449-53.

18. Ohayon MM, Guilleminault C, Priest RG, Caulet M. Snoring and breathing pauses during sleep: telephone interview survey of a United Kingdom population sample. BMJ. 1997;314(7084):860-3.

19. Zielinski J, Zgierska A, Polakowska M, Finn L, Kurjata P, Kupsc W, et al. Snoring and excessive daytime somnolence among Polish middle-aged adults. Eur Respir J.

1999;14(4):946-50. 
20. Jennum P, Riha RL. Epidemiology of sleep apnoea/hypopnoea syndrome and sleepdisordered breathing. Eur Respir J. 2009;33(4):907-14.

21. Young T, Shahar E, Nieto FJ, Redline S, Newman AB, Gottlieb DJ, et al. Predictors of sleep-disordered breathing in community-dwelling adults: the Sleep Heart Health Study. Archives of internal medicine. 2002;162(8):893-900.

22. Young T, Palta M, Dempsey J, Skatrud J, Weber S, Badr S. The occurrence of sleepdisordered breathing among middle-aged adults. N Engl J Med. 1993;328(17):1230-5.

23. Obstructive Sleep Apnoea Syndrome. Report of a joint Nordic project. A systematic review.: Swedish Council on Technology Assessment in Healt Care (SBU); 2007.

24. Svanborg E. Upper airway nerve lesions in obstructive sleep apnea. American journal of respiratory and critical care medicine. 2001;164(2):187-9.

25. Moyer CA, Sonnad SS, Garetz SL, Helman JI, Chervin RD. Quality of life in obstructive sleep apnea: a systematic review of the literature. Sleep Med. 2001;2(6):477-91. 26. Sassani A, Findley LJ, Kryger M, Goldlust E, George C, Davidson TM. Reducing motor-vehicle collisions, costs, and fatalities by treating obstructive sleep apnea syndrome. Sleep. 2004;27(3):453-8.

27. Lindberg E, Carter N, Gislason T, Janson C. Role of snoring and daytime sleepiness in occupational accidents. American journal of respiratory and critical care medicine. 2001;164(11):2031-5.

28. Peppard PE, Young T, Palta M, Skatrud J. Prospective study of the association between sleep-disordered breathing and hypertension. N Engl J Med. 2000;342(19):1378-84.

29. Konecny T, Kara T, Somers VK. Obstructive sleep apnea and hypertension: an update. Hypertension. 2014;63(2):203-9.

30. Freet CS, Stoner JF, Tang X. Baroreflex and chemoreflex controls of sympathetic activity following intermittent hypoxia. Autonomic neuroscience : basic \& clinical.

2013;174(1-2):8-14.

31. Dong JY, Zhang YH, Qin LQ. Obstructive sleep apnea and cardiovascular risk: metaanalysis of prospective cohort studies. Atherosclerosis. 2013;229(2):489-95.

32. Lam JC, Ip MS. An update on obstructive sleep apnea and the metabolic syndrome. Curr Opin Pulm Med. 2007;13(6):484-9.

33. McNicholas WT. Obstructive sleep apnea and inflammation. Prog Cardiovasc Dis. 2009;51(5):392-9.

34. Araghi MH, Chen YF, Jagielski A, Choudhury S, Banerjee D, Hussain S, et al. Effectiveness of lifestyle interventions on obstructive sleep apnea (OSA): systematic review and meta-analysis. Sleep. 2013;36(10):1553-62, 62A-62E.

35. Ashrafian H, Toma T, Rowland SP, Harling L, Tan A, Efthimiou E, et al. Bariatric Surgery or Non-Surgical Weight Loss for Obstructive Sleep Apnoea? A Systematic Review and Comparison of Meta-analyses. Obesity surgery. 2014.

36. Mortimore IL, Kochhar P, Douglas NJ. Effect of chronic continuous positive airway pressure (CPAP) therapy on upper airway size in patients with sleep apnoea/hypopnoea syndrome. Thorax. 1996;51(2):190-2.

37. Sullivan CE, Issa FG, Berthon-Jones M, Eves L. Reversal of obstructive sleep apnoea by continuous positive airway pressure applied through the nares. Lancet. 1981;1(8225):8625 .

38. Guilleminault C, Kreutzer M, Chang JL. Pregnancy, sleep disordered breathing and treatment with nasal continuous positive airway pressure. Sleep Med. 2004;5(1):43-51.

39. Loube DI, Poceta JS, Morales MC, Peacock MD, Mitler MM. Self-reported snoring in pregnancy. Association with fetal outcome. Chest. 1996;109(4):885-9. 
40. Ayrim A, Keskin EA, Ozol D, Onaran Y, Yiidirim Z, Kafali H. Influence of selfreported snoring and witnessed sleep apnea on gestational hypertension and fetal outcome in pregnancy. Arch Gynecol Obstet. 2011;283(2):195-9.

41. Guilleminault C, Querra-Salva M, Chowdhuri S, Poyares D. Normal pregnancy, daytime sleeping, snoring and blood pressure. Sleep Med. 2000;1(4):289-97.

42. Perez-Chada D, Videla AJ, O'Flaherty ME, Majul C, Catalini AM, Caballer CA, et al. Snoring, witnessed sleep apnoeas and pregnancy-induced hypertension. Acta Obstet Gynecol Scand. 2007;86(7):788-92.

43. Izci Balserak B, Jackson N, Ratcliffe SA, Pack AI, Pien GW. Sleep-disordered breathing and daytime napping are associated with maternal hyperglycemia. Sleep \& breathing = Schlaf \& Atmung. 2013;17(3):1093-102.

44. Olivarez SA, Ferres M, Antony K, Mattewal A, Maheshwari B, Sangi-Haghpeykar H, et al. Obstructive sleep apnea screening in pregnancy, perinatal outcomes, and impact of maternal obesity. American journal of perinatology. 2011;28(8):651-8.

45. K.A. E. Restless Legs: a clinical study. Acta medica Scandinavica Supplementum. 1945;158:1-123.

46. Allen RP, Picchietti D, Hening WA, Trenkwalder C, Walters AS, Montplaisi J, et al. Restless legs syndrome: diagnostic criteria, special considerations, and epidemiology. A report from the restless legs syndrome diagnosis and epidemiology workshop at the National Institutes of Health. Sleep Med. 2003;4(2):101-19.

47. Allen RP, Walters AS, Montplaisir J, Hening W, Myers A, Bell TJ, et al. Restless legs syndrome prevalence and impact: REST general population study. Archives of internal medicine. 2005;165(11):1286-92.

48. Ohayon MM, O'Hara R, Vitiello MV. Epidemiology of restless legs syndrome: a synthesis of the literature. Sleep medicine reviews. 2012;16(4):283-95.

49. Berger K, Luedemann J, Trenkwalder C, John U, Kessler C. Sex and the risk of restless legs syndrome in the general population. Archives of internal medicine.

2004;164(2):196-202.

50. Pantaleo NP, Hening WA, Allen RP, Earley CJ. Pregnancy accounts for most of the gender difference in prevalence of familial RLS. Sleep Med. 2010;11(3):310-3.

51. Montplaisir J, Boucher S, Poirier G, Lavigne G, Lapierre O, Lesperance P. Clinical, polysomnographic, and genetic characteristics of restless legs syndrome: a study of 133 patients diagnosed with new standard criteria. Movement disorders : official journal of the Movement Disorder Society. 1997;12(1):61-5.

52. Ferri R, Rundo F, Zucconi M, Manconi M, Bruni O, Ferini-Strambi L, et al. An Evidence-based Analysis of the Association between Periodic Leg Movements during Sleep and Arousals in Restless Legs Syndrome. Sleep. 2015.

53. Pichler I, Hicks AA, Pramstaller PP. Restless legs syndrome: an update on genetics and future perspectives. Clinical genetics. 2008;73(4):297-305.

54. Earley CJ, Allen RP, Beard JL, Connor JR. Insight into the pathophysiology of restless legs syndrome. Journal of neuroscience research. 2000;62(5):623-8.

55. Allen RP, Earley CJ. The role of iron in restless legs syndrome. Movement disorders : official journal of the Movement Disorder Society. 2007;22 Suppl 18:S440-8.

56. Sun YM, Hoang T, Neubauer JA, Walters AS. Opioids protect against substantia nigra cell degeneration under conditions of iron deprivation: a mechanism of possible relevance to the Restless Legs Syndrome (RLS) and Parkinson's disease. Journal of the neurological sciences. 2011;304(1-2):93-101.

57. Walters AS, Ondo WG, Zhu W, Le W. Does the endogenous opiate system play a role in the Restless Legs Syndrome? A pilot post-mortem study. Journal of the neurological sciences. 2009;279(1-2):62-5. 
58. Anderson KN, Di Maria C, Allen J. Novel assessment of microvascular changes in idiopathic restless legs syndrome (Willis-Ekbom disease). Journal of sleep research. 2013;22(3):315-21.

59. Happe S, Zeitlhofer J. Abnormal cutaneous thermal thresholds in patients with restless legs syndrome. Journal of neurology. 2003;250(3):362-5.

60. Sieminski M. Restless legs syndrome -- secondary, comorbid or coincidental? European neurology. 2013;69(3):150-1.

61. Trenkwalder C, Paulus W, Walters AS. The restless legs syndrome. Lancet neurology. 2005;4(8):465-75.

62. Garcia-Borreguero D, Kohnen R, Silber MH, Winkelman JW, Earley CJ, Hogl B, et al. The long-term treatment of restless legs syndrome/Willis-Ekbom disease: evidence-based guidelines and clinical consensus best practice guidance: a report from the International Restless Legs Syndrome Study Group. Sleep Med. 2013;14(7):675-84.

63. Garcia-Borreguero D, Ferini-Strambi L, Kohnen R, O'Keeffe S, Trenkwalder C, Hogl $\mathrm{B}$, et al. European guidelines on management of restless legs syndrome: report of a joint task force by the European Federation of Neurological Societies, the European Neurological Society and the European Sleep Research Society. European journal of neurology : the official journal of the European Federation of Neurological Societies. 2012;19(11):1385-96. 64. Silber MH, Becker PM, Earley C, Garcia-Borreguero D, Ondo WG, Medical Advisory Board of the Willis-Ekbom Disease F. Willis-Ekbom Disease Foundation revised consensus statement on the management of restless legs syndrome. Mayo Clinic proceedings. 2013;88(9):977-86.

65. Aurora RN, Kristo DA, Bista SR, Rowley JA, Zak RS, Casey KR, et al. Update to the AASM Clinical Practice Guideline: "The treatment of restless legs syndrome and periodic limb movement disorder in adults-an update for 2012: practice parameters with an evidencebased systematic review and meta-analyses". Sleep. 2012;35(8):1037.

66. Srivanitchapoom P, Pandey S, Hallett M. Restless legs syndrome and pregnancy: a review. Parkinsonism \& related disorders. 2014;20(7):716-22.

67. Tunc T, Karadag YS, Dogulu F, Inan LE. Predisposing factors of restless legs syndrome in pregnancy. Movement disorders : official journal of the Movement Disorder Society. 2007;22(5):627-31.

68. Manconi M, Govoni V, De Vito A, Economou NT, Cesnik E, Casetta I, et al. Restless legs syndrome and pregnancy. Neurology. 2004;63(6):1065-9.

69. Ramirez JO, Cabrera SA, Hidalgo H, Cabrera SG, Linnebank M, Bassetti CL, et al. Is preeclampsia associated with restless legs syndrome? Sleep Med. 2013.

70. Vahdat M, Sariri E, Miri S, Rohani M, Kashanian M, Sabet A, et al. Prevalence and associated features of restless legs syndrome in a population of Iranian women during pregnancy. Int J Gynaecol Obstet. 2013.

71. Wesstrom J, Skalkidou A, Manconi M, Fulda S, Sundstrom-Poromaa I. Prepregnancy restless legs syndrome (Willis-Ekbom Disease) is associated with perinatal depression. Journal of clinical sleep medicine : JCSM : official publication of the American Academy of Sleep Medicine. 2014;10(5):527-33.

72. Picchietti DL, Hensley JG, Bainbridge JL, Lee KA, Manconi M, McGregor JA, et al. Consensus clinical practice guidelines for the diagnosis and treatment of restless legs syndrome/Willis-Ekbom disease during pregnancy and lactation. Sleep medicine reviews. 2014.

73. Josefsson A, Berg G, Nordin C, Sydsjo G. Prevalence of depressive symptoms in late pregnancy and postpartum. Acta Obstet Gynecol Scand. 2001;80(3):251-5. 
74. Milgrom J, Gemmill AW, Bilszta JL, Hayes B, Barnett B, Brooks J, et al. Antenatal risk factors for postnatal depression: a large prospective study. Journal of affective disorders. 2008;108(1-2):147-57.

75. Hirst KP, Moutier CY. Postpartum major depression. American family physician. 2010;82(8):926-33.

76. Soares CN, Zitek B. Reproductive hormone sensitivity and risk for depression across the female life cycle: a continuum of vulnerability? Journal of psychiatry \& neuroscience : JPN. 2008;33(4):331-43.

77. Corwin EJ, Pajer K. The psychoneuroimmunology of postpartum depression. Journal of women's health. 2008;17(9):1529-34.

78. Wisner KL, Peindl KS, Gigliotti T, Hanusa BH. Obsessions and compulsions in women with postpartum depression. The Journal of clinical psychiatry. 1999;60(3):176-80.

79. Kingston D, Tough S, Whitfield $H$. Prenatal and postpartum maternal psychological distress and infant development: a systematic review. Child psychiatry and human development. 2012;43(5):683-714.

80. Field T. Postpartum depression effects on early interactions, parenting, and safety practices: A review. Infant Behav Dev. 2010;33(1):1-6.

81. Dennis CL, Hodnett E. Psychosocial and psychological interventions for treating postpartum depression. The Cochrane database of systematic reviews. 2007(4):CD006116.

82. Wisner KL, Parry BL, Piontek CM. Clinical practice. Postpartum depression. N Engl J Med. 2002;347(3):194-9.

83. Weissman AM, Levy BT, Hartz AJ, Bentler S, Donohue M, Ellingrod VL, et al. Pooled analysis of antidepressant levels in lactating mothers, breast milk, and nursing infants. The American journal of psychiatry. 2004;161(6):1066-78.

84. Dennis CL, Dowswell T. Psychosocial and psychological interventions for preventing postpartum depression. The Cochrane database of systematic reviews. 2013;2:CD001134.

85. Tsuno N, Besset A, Ritchie K. Sleep and depression. The Journal of clinical psychiatry. 2005;66(10):1254-69.

86. Benca RM, Obermeyer WH, Thisted RA, Gillin JC. Sleep and psychiatric disorders. A meta-analysis. Archives of general psychiatry. 1992;49(8):651-68; discussion 69-70.

87. Steiger A, Kimura M. Wake and sleep EEG provide biomarkers in depression. Journal of psychiatric research. 2010;44(4):242-52.

88. Toffol E, Kalleinen N, Urrila AS, Himanen SL, Porkka-Heiskanen T, Partonen T, et al. The relationship between mood and sleep in different female reproductive states. BMC psychiatry. 2014;14:177.

89. Riemann D, Berger M, Voderholzer U. Sleep and depression--results from psychobiological studies: an overview. Biological psychology. 2001;57(1-3):67-103. 90. Breslau N, Roth T, Rosenthal L, Andreski P. Sleep disturbance and psychiatric disorders: a longitudinal epidemiological study of young adults. Biological psychiatry. 1996;39(6):411-8.

91. Cole MG, Dendukuri N. Risk factors for depression among elderly community subjects: a systematic review and meta-analysis. The American journal of psychiatry. 2003;160(6):1147-56.

92. Skouteris H, Germano C, Wertheim EH, Paxton SJ, Milgrom J. Sleep quality and depression during pregnancy: a prospective study. Journal of sleep research. 2008;17(2):21720.

93. Kamysheva E, Skouteris H, Wertheim EH, Paxton SJ, Milgrom J. A prospective investigation of the relationships among sleep quality, physical symptoms, and depressive symptoms during pregnancy. Journal of affective disorders. 2010;123(1-3):317-20. 
94. Mellor R, Chua SC, Boyce P. Antenatal depression: an artefact of sleep disturbance? Archives of women's mental health. 2014.

95. Dorheim SK, Bondevik GT, Eberhard-Gran M, Bjorvatn B. Sleep and depression in postpartum women: a population-based study. Sleep. 2009;32(7):847-55.

96. Wolfson AR, Crowley SJ, Anwer U, Bassett JL. Changes in sleep patterns and depressive symptoms in first-time mothers: last trimester to 1-year postpartum. Behavioral sleep medicine. 2003;1(1):54-67.

97. Okun ML, Hanusa BH, Hall M, Wisner KL. Sleep complaints in late pregnancy and the recurrence of postpartum depression. Behavioral sleep medicine. 2009;7(2):106-17.

98. Park EM, Meltzer-Brody S, Stickgold R. Poor sleep maintenance and subjective sleep quality are associated with postpartum maternal depression symptom severity. Archives of women's mental health. 2013.

99. Marques M, Bos S, Soares MJ, Maia B, Pereira AT, Valente J, et al. Is insomnia in late pregnancy a risk factor for postpartum depression/depressive symptomatology? Psychiatry research. 2011;186(2-3):272-80.

100. Dorheim SK, Bjorvatn B, Eberhard-Gran M. Can insomnia in pregnancy predict postpartum depression? A longitudinal, population-based study. PloS one. 2014;9(4):e94674. 101. Bei B, Milgrom J, Ericksen J, Trinder J. Subjective perception of sleep, but not its objective quality, is associated with immediate postpartum mood disturbances in healthy women. Sleep. 2010;33(4):531-8.

102. Coo S, Milgrom J, Trinder J. Mood and Objective and Subjective Measures of Sleep During Late Pregnancy and the Postpartum Period. Behavioral sleep medicine. 2013.

103. August EM, Salihu HM, Biroscak BJ, Rahman S, Bruder K, Whiteman VE.

Systematic review on sleep disorders and obstetric outcomes: scope of current knowledge. American journal of perinatology. 2013;30(4):323-34.

104. Ding XX, Wu YL, Xu SJ, Zhang SF, Jia XM, Zhu RP, et al. A systematic review and quantitative assessment of sleep-disordered breathing during pregnancy and perinatal outcomes. Sleep \& breathing = Schlaf \& Atmung. 2014.

105. Pamidi S, Pinto LM, Marc I, Benedetti A, Schwartzman K, Kimoff RJ. Maternal Sleep-Disordered Breathing and Adverse Pregnancy Outcomes - A Systematic Review and Meta-analysis. Am J Obstet Gynecol. 2013.

106. Broughton Pipkin F, Roberts JM. Hypertension in pregnancy. Journal of human hypertension. 2000;14(10-11):705-24.

107. International statistical classification of diseases and related health problems : ICD10. Geneva: World Health Organization; 2009.

108. ACOG technical bulletin. Hypertension in pregnancy. Number 219--January 1996 (replaces no. 91, February 1986). Committee on Technical Bulletins of the American College of Obstetricians and Gynecologists. Int J Gynaecol Obstet. 1996;53(2):175-83.

109. Hernandez-Diaz S, Toh S, Cnattingius S. Risk of pre-eclampsia in first and subsequent pregnancies: prospective cohort study. Bmj. 2009;338:b2255.

110. Redman CW, Sacks GP, Sargent IL. Preeclampsia: an excessive maternal inflammatory response to pregnancy. Am J Obstet Gynecol. 1999;180(2 Pt 1):499-506.

111. Franklin KA, Holmgren PA, Jonsson F, Poromaa N, Stenlund H, Svanborg E. Snoring, pregnancy-induced hypertension, and growth retardation of the fetus. Chest. 2000;117(1):137-41.

112. The Swedish Medical Birth Register 1973-2011. Stockholm: Centre for Epidemiology, National Board of Health and Welfare; 2013.

113. Johns MW. A new method for measuring daytime sleepiness: the Epworth sleepiness scale. Sleep. 1991;14(6):540-5. 
114. Baumgartel KL, Terhorst L, Conley YP, Roberts JM. Psychometric evaluation of the Epworth Sleepiness Scale in an obstetric population. Sleep Med. 2013;14(1):116-21.

115. Ulander M, Arestedt K, Svanborg E, Johansson P, Brostrom A. The fairness of the Epworth Sleepiness Scale: two approaches to differential item functioning. Sleep \& breathing $=$ Schlaf \& Atmung. 2013;17(1):157-65.

116. Cox JL, Holden JM, Sagovsky R. Detection of postnatal depression. Development of the 10-item Edinburgh Postnatal Depression Scale. The British journal of psychiatry : the journal of mental science. 1987;150:782-6.

117. Murray L, Carothers AD. The validation of the Edinburgh Post-natal Depression Scale on a community sample. The British journal of psychiatry : the journal of mental science. 1990;157:288-90.

118. Wickberg B, Hwang CP. The Edinburgh Postnatal Depression Scale: validation on a Swedish community sample. Acta psychiatrica Scandinavica. 1996;94(3):181-4.

119. International Labour Office. International standard classification of occupations : ISCO-88. Rev. ed. Geneva: International Labour Office; 1990. vii, 457 p p.

120. Sunnergren O, Brostrom A, Svanborg E. Positional sensitivity as a confounder in diagnosis of severity of obstructive sleep apnea. Sleep \& breathing = Schlaf \& Atmung. 2013;17(1):173-9.

121. Douglas NJ, Thomas S, Jan MA. Clinical value of polysomnography. Lancet. 1992;339(8789):347-50.

122. Berry RB, Hill G, Thompson L, McLaurin V. Portable monitoring and autotitration versus polysomnography for the diagnosis and treatment of sleep apnea. Sleep. 2008;31(10):1423-31.

123. Collop NA, Anderson WM, Boehlecke B, Claman D, Goldberg R, Gottlieb DJ, et al. Clinical guidelines for the use of unattended portable monitors in the diagnosis of obstructive sleep apnea in adult patients. Portable Monitoring Task Force of the American Academy of Sleep Medicine. Journal of clinical sleep medicine : JCSM : official publication of the American Academy of Sleep Medicine. 2007;3(7):737-47.

124. Sverige. Justitiedepartementet. Behandling av personuppgifter : information om personuppgiftslagen. 4., rev. uppl. ed. Stockholm: Justitiedepartementet Fritzes distributör; 2006. 28 s. p.

125. Johns MW. Daytime sleepiness, snoring, and obstructive sleep apnea. The Epworth Sleepiness Scale. Chest. 1993;103(1):30-6.

126. Johns MW. Sleepiness in different situations measured by the Epworth Sleepiness Scale. Sleep. 1994;17(8):703-10.

127. Miletin MS, Hanly PJ. Measurement properties of the Epworth sleepiness scale. Sleep Med. 2003;4(3):195-9.

128. Kendzerska TB, Smith PM, Brignardello-Petersen R, Leung RS, Tomlinson GA. Evaluation of the measurement properties of the Epworth sleepiness scale: a systematic review. Sleep medicine reviews. 2014;18(4):321-31.

129. Harris B, Huckle P, Thomas R, Johns S, Fung H. The use of rating scales to identify post-natal depression. The British journal of psychiatry : the journal of mental science. 1989;154:813-7.

130. Kozinszky Z, Dudas RB. Validation studies of the Edinburgh Postnatal Depression Scale for the antenatal period. Journal of affective disorders. 2015;176C:95-105.

131. Ursavas A, Karadag M, Nalci N, Ercan I, Gozu RO. Self-reported snoring, maternal obesity and neck circumference as risk factors for pregnancy-induced hypertension and preeclampsia. Respiration. 2008;76(1):33-9.

132. Simpson AP. Dynamic consequences of differences in male and female vocal tract dimensions. The Journal of the Acoustical Society of America. 2001;109(5 Pt 1):2153-64. 
133. Martin SE, Mathur R, Marshall I, Douglas NJ. The effect of age, sex, obesity and posture on upper airway size. Eur Respir J. 1997;10(9):2087-90.

134. KL M, AF D. Clinically Oriented Anatomy. 6 ed. Baltimore: Williams and Wilkins; 2009.

135. Douglas NJ. Home diagnosis of the obstructive sleep apnoea/hypopnoea syndrome. Sleep medicine reviews. 2003;7(1):53-9.

136. Gay PC, Selecky PA. Are sleep studies appropriately done in the home? Respiratory care. 2010;55(1):66-75.

137. Antony KM, Agrawal A, Arndt ME, Murphy AM, Alapat PM, Guntupalli KK, et al. Obstructive sleep apnea in pregnancy: reliability of prevalence and prediction estimates.

Journal of perinatology : official journal of the California Perinatal Association. 2014.

138. Sahin FK, Koken G, Cosar E, Saylan F, Fidan F, Yilmazer M, et al. Obstructive sleep apnea in pregnancy and fetal outcome. Int J Gynaecol Obstet. 2008;100(2):141-6.

139. Champagne K, Schwartzman K, Opatrny L, Barriga P, Morin L, Mallozzi A, et al. Obstructive sleep apnoea and its association with gestational hypertension. Eur Respir J. 2009;33(3):559-65.

140. Reid J, Skomro R, Cotton D, Ward H, Olatunbosun F, Gjevre J, et al. Pregnant women with gestational hypertension may have a high frequency of sleep disordered breathing. Sleep. 2011;34(8):1033-8.

141. Facco FL, Ouyang DW, Zee PC, Grobman WA. Sleep Disordered Breathing in a High-Risk Cohort Prevalence and Severity across Pregnancy. American journal of perinatology. 2014.

142. Facco FL, Lappen J, Lim C, Zee PC, Grobman WA. Preeclampsia and SleepDisordered Breathing: A Case-Control Study. Pregnancy hypertension. 2013;3(2):133-9.

143. Louis J, Auckley D, Miladinovic B, Shepherd A, Mencin P, Kumar D, et al. Perinatal outcomes associated with obstructive sleep apnea in obese pregnant women. Obstetrics and gynecology. 2012;120(5):1085-92.

144. Suzuki K, Ohida T, Sone T, Takemura S, Yokoyama E, Miyake T, et al. The prevalence of restless legs syndrome among pregnant women in Japan and the relationship between restless legs syndrome and sleep problems. Sleep. 2003;26(6):673-7.

145. Lee KA, Zaffke ME, Baratte-Beebe K. Restless legs syndrome and sleep disturbance during pregnancy: the role of folate and iron. Journal of women's health \& gender-based medicine. 2001;10(4):335-41.

146. Hedman C, Pohjasvaara T, Tolonen U, Suhonen-Malm AS, Myllyla VV. Effects of pregnancy on mothers' sleep. Sleep Med. 2002;3(1):37-42.

147. Hubner A, Krafft A, Gadient S, Werth E, Zimmermann R, Bassetti CL.

Characteristics and determinants of restless legs syndrome in pregnancy: a prospective study. Neurology. 2013;80(8):738-42.

148. Roux FJ. Restless legs syndrome: impact on sleep-related breathing disorders. Respirology. 2013;18(2):238-45.

149. Terzi H, Terzi R, Zeybek B, Ergenoglu M, Hacivelioglu S, Akdemir A, et al. Restless legs syndrome is related to obstructive sleep apnea symptoms during pregnancy. Sleep \& breathing $=$ Schlaf $\&$ Atmung. 2014.

150. Goodman JD, Brodie C, Ayida GA. Restless leg syndrome in pregnancy. BMJ. 1988;297(6656):1101-2.

151. Uglane MT, Westad S, Backe B. Restless legs syndrome in pregnancy is a frequent disorder with a good prognosis. Acta Obstet Gynecol Scand. 2011;90(9):1046-8.

152. Cesnik E, Casetta I, Turri M, Govoni V, Granieri E, Strambi LF, et al. Transient RLS during pregnancy is a risk factor for the chronic idiopathic form. Neurology.

2010;75(23):2117-20. 
153. Xiong L, Montplaisir J, Desautels A, Barhdadi A, Turecki G, Levchenko A, et al. Family study of restless legs syndrome in Quebec, Canada: clinical characterization of 671 familial cases. Archives of neurology. 2010;67(5):617-22.

154. Signal TL, Paine SJ, Sweeney B, Priston M, Muller D, Smith A, et al. Prevalence of abnormal sleep duration and excessive daytime sleepiness in pregnancy and the role of sociodemographic factors: comparing pregnant women with women in the general population. Sleep Med. 2014;15(12):1477-83.

155. Ko H, Shin J, Kim MY, Kim YH, Lee J, Kil KC, et al. Sleep disturbances in Korean pregnant and postpartum women. Journal of psychosomatic obstetrics and gynaecology. 2012;33(2):85-90.

156. Bourjeily G, Raker C, Chalhoub M, Miller M. Excessive daytime sleepiness in late pregnancy may not always be normal: results from a cross-sectional study. Sleep \& breathing $=$ Schlaf \& Atmung. 2013;17(2):735-40.

157. Izci B, Martin SE, Dundas KC, Liston WA, Calder AA, Douglas NJ. Sleep complaints: snoring and daytime sleepiness in pregnant and pre-eclamptic women. Sleep Med. 2005;6(2):163-9.

158. Chang JJ, Pien GW, Duntley SP, Macones GA. Sleep deprivation during pregnancy and maternal and fetal outcomes: is there a relationship? Sleep medicine reviews. 2010;14(2):107-14.

159. Palagini L, Gemignani A, Banti S, Manconi M, Mauri M, Riemann D. Chronic sleep loss during pregnancy as a determinant of stress: impact on pregnancy outcome. Sleep Med. 2014;15(8):853-9.

160. Picchietti D, Winkelman JW. Restless legs syndrome, periodic limb movements in sleep, and depression. Sleep. 2005;28(7):891-8.

161. Li Y, Mirzaei F, O'Reilly EJ, Winkelman J, Malhotra A, Okereke OI, et al. Prospective study of restless legs syndrome and risk of depression in women. American journal of epidemiology. 2012;176(4):279-88.

162. Becker PM, Sharon D. Mood disorders in restless legs syndrome (Willis-Ekbom disease). The Journal of clinical psychiatry. 2014;75(7):e679-94.

163. Gaynes BN, Gavin N, Meltzer-Brody S, Lohr KN, Swinson T, Gartlehner G, et al. Perinatal depression: prevalence, screening accuracy, and screening outcomes. Evidence report/technology assessment. 2005(119):1-8.

164. Fung AM, Wilson DL, Barnes M, Walker SP. Obstructive sleep apnea and pregnancy: the effect on perinatal outcomes. Journal of perinatology : official journal of the California Perinatal Association. 2012;32(6):399-406.

165. Simpson N, Dinges DF. Sleep and inflammation. Nutrition reviews. 2007;65(12 Pt 2):S244-52.

166. Richardson AC, Carpenter MW. Inflammatory mediators in gestational diabetes mellitus. Obstetrics and gynecology clinics of North America. 2007;34(2):213-24, viii.

167. de Heredia FP, Gomez-Martinez S, Marcos A. Obesity, inflammation and the immune system. The Proceedings of the Nutrition Society. 2012;71(2):332-8.

168. Cedergren M. Effects of gestational weight gain and body mass index on obstetric outcome in Sweden. Int J Gynaecol Obstet. 2006;93(3):269-74.

169. Pregnancies, Deliveries and Newborn Infants The Swedish Medical Birth Register 1973-2013. www.socialstyrelsen.se 2014. 
Kryssa för det alternativ som bäst beskriver situationen

\begin{tabular}{|l|l|l|l|l|l|l|l|l|}
\hline Dagens datum: & Aldrig & Sällan & Ibland & Ofta & Alltid & Vet ej \\
\hline Snarkar Du? & & & & & & & \\
\hline
\end{tabular}

Om Du snarkar "ofta" eller "alltid", ungefär hur länge har det varit så? (veckor, dagar, år.?.)................

\begin{tabular}{|l|l|l|l|l|l|l|}
\hline & Aldrig & Sällan & Ibland & Ofta & Alltid & Vet ej \\
\hline $\begin{array}{l}\text { Har någon berättat för Dig, att Du har andningsuppehåll } \\
\text { när Du sover? }\end{array}$ & & & & & & \\
\hline
\end{tabular}

Om Du har andningsuppehåll "ofta" eller "alltid", ungefär hur länge tror Du att Du haft det?

(veckor, dagar, år.?)..........................

\begin{tabular}{|l|l|l|l|l|l|l|}
\hline & Aldrig & Sällan & Ibland & Ofta & Alltid & Vet ej \\
\hline \hline $\begin{array}{l}\text { Känner Du Dig trött och dåligt utvilad då } \\
\text { Du vaknar på morgonen? }\end{array}$ & & & & & & \\
\hline Är Du sömnig under dagen? & & & & & & \\
\hline
\end{tabular}

Känner Du Dig mer svullen i kroppen än vanligt. Syftar på ökad vätskemängd i vävnaden (inte ökat bukomfång pga barnet eller ökad mängd fett) och märks lättast i händer, fötter och ben.

$\square$ Nej, inte alls $\quad \square$ Ja, lite $\square$ Ja, måttligt $\quad \square$ Ja, mycket $\quad$ Var/vilken kroppsdel?

- Har Du obehagliga förnimmelser (myrkrypningar) i benen kombinerat med ett starkt behov av att röra på benen? $\square \quad \mathrm{Ja} \quad \square \quad \mathrm{Nej}$

- Uppträder dessa besvär huvudsakligen eller endast vid vila och avtar de när Du rör på Dig?

$$
\square \quad \mathrm{Ja} \quad \square \quad \mathrm{Nej}
$$

- Är dessa besvär värre på kvällen eller under natten, jämfört med på morgonen?

$\begin{array}{lccc} & & \text { Ja } & \square \quad \text { Nej } \\ \text { - Hur ofta uppträder dessa besvär? } & \square \quad & \text { mindre än en gång om året? }\end{array}$

minst en gång om året men mindre än en gång i månaden

en gång i månaden

2-4 gånger i månaden

2-4 gånger i veckan

4-5 gånger i veckan

6-7 gånger i veckan

\section{Epworth's sömnskala}

Hur troligt är det, att Du skulle slumra till eller somna i följande situationer, till skillnad från att enbart känna Dig trött? Det avser Ditt vanliga levnadssätt på senaste tiden. Även om Du inte gjort allt detta nyligen, så försök att komma på hur det skulle ha påverkat Dig. Använd nedanstående skala för att välja den lämpligaste siffran för varje situation.

$0=$ skulle aldrig slumra

$1=$ liten risk att slumra

$2=$ måttlig risk att slumra

$3=$ stor risk att slumra

\section{Situation}

Sitter och läser

Tittar på TV

Sitter overksam på allmän plats (t.ex. teater eller ett möte)

Som passagerare $\mathrm{i}$ en bil $\mathrm{i}$ en timme utan paus

Ligger och vilar på eftermiddagen om omständigheterna tillåter

Sitter och pratar med någon.

Sitter stilla efter att ha ätit lunch (utan alkohol)

I en bil som stannat några minuter $\mathrm{i}$ trafiken

\section{Risk att slumra}

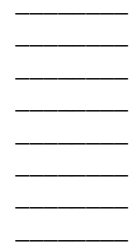

Summa: 


\section{Appendix 2}

\section{Sinnesstämning - Hur har du mått de senaste 7 dagarna: \\ Ringa in det alternativ som Du tycker överensstämmer bäst i följande 10 frågor:}

1. Jag har kunnat se tillvaron från den ljusa sidan.

Lika bra som vanligt

Nästan lika bra som vanligt

Mycket mindre än vanligt

Inte alls

2. Jag har glatt mig åt saker som skall hända.

Lika mycket som vanligt

Något mindre än vanligt

Mycket mindre än vanligt

Inte alls

3. Jag har lagt skulden på mig själv onödigt mycket när något gått snett.

Ja, för det mesta

Ja, ibland

Inte så ofta

Nej, aldrig

4. Jag har känt mig rädd och orolig utan egentlig anledning.

Nej, inte alls

Knappast alls
Ja, ibland
Ja, mycket ofta

5. Jag har känt mig skrämd eller panikslagen utan speciell anledning.

Ja, mycket ofta

Ja, ibland

Nej, ganska sällan

Aldrig
6. Det har kört ihop sig för mig och blivit för mycket.

Ja, mesta tiden har jag inte kunnat ta itu med något alls

Ja, ibland har jag inte kunnat ta itu med saker lika bra som vanligt

Nej, för det mesta har jag kunnat ta itu med saker ganska bra

Nej, jag har kunnat ta itu med saker precis som vanligt

7. Jag har känt mig så ledsen och olycklig att jag har haft svårt att sova.

Ja, för det mesta

Ja, ibland

Nej, sällan

Nej, aldrig

8. Jag har känt mig ledsen och nere.

Ja, för det mesta

Ja, rätt ofta

Nej, sällan

Nej, aldrig

9. Jag har känt mig så olycklig att jag har gråtit

Ja, nästan jämt

Ja, ganska ofta

Bara någon gång

Nej, inte alls

10. Tankar på att göra mig själv illa har förekommit

Ja, rätt ofta

Ja, då och då

Knappast alls

Aldrig 


\section{Errata}

Paper I: Snoring during pregnancy and its relation to sleepiness and pregnancy outcome - a prospective study. BMC Pregnancy and Childbirth 2014;14:15.

\begin{tabular}{|l|l|l|}
\hline Page/column/line & Original text & Correction \\
\hline $\begin{array}{l}\text { Page 3/column 2 } \\
\text { /line 1 }\end{array}$ & $\begin{array}{l}\text { a greater share of the } \\
\text { "habitual snorers" were } \\
\text { classified as obese }\end{array}$ & $\begin{array}{l}\text { a greater share of the } \\
\text { "habitual snorers" were } \\
\text { classified as obese (BMI } \geq 30)\end{array}$ \\
\hline $\begin{array}{l}\text { Page 6/column 1 } \\
\text { /line 44 }\end{array}$ & $\begin{array}{l}\text { The drop-out rate from } \\
\text { inclusion to the } \\
\text { measurement in the 3 } \\
68 \%\end{array}$ & $\begin{array}{l}\text { The drop-out rate from } \\
\text { inclusion to the measurement } \\
\text { in the 3 } 3^{\text {rd }} \text { trimester was 32\% }\end{array}$ \\
\hline
\end{tabular}

Paper II: Restless legs syndrome during and after pregnancy and its relation to snoring, Acta Obstet Gynecol Scand 2012;91:850-855

\begin{tabular}{|l|l|l|}
\hline Page/column/line & Original text & Correction \\
\hline Page 852/Table 1 & & $\begin{array}{l}\text { Numbers concerning age, } \\
\text { weight and body mass index } \\
\text { should be displayed under } \\
\text { "mean" and "SD" }\end{array}$ \\
\hline $\begin{array}{l}\text { Page 852/column 2 } \\
\text { /line 5 }\end{array}$ & $\begin{array}{l}\text { (p=0.04 and 0.046 } \\
\text { respectively) }\end{array}$ & $\begin{array}{l}\mathrm{p}=0.004 \text { and } 0.049 \\
\text { respectively) }\end{array}$ \\
\hline Page 852/Figure 1 & $\mathrm{p}<0.003$ & $\mathrm{p}=0.003$ \\
\hline
\end{tabular}




\section{Publications}

The articles associated with this thesis have been removed for copyright reasons. For more details about these see:

http://urn.kb.se/resolve?urn=urn:nbn:se:liu:diva-117869 